A N N A LE S

UNIVERSITATIS MARIAE CURIE-SKŁODOWSKA LUBLIN - POLONIA

VOL. LXXI

SECTIO F

2016

Uniwersytet Marii Curie-Skłodowskiej w Lublinie

Wydział Humanistyczny

\title{
JAN GAWRON
}

\section{Czarna legenda biskupa krakowskiego Pawła z Przemankowa}

The Dark Legend of Paweł of Przemanków, the Bishop of Cracow

\section{STRESZCZENIE}

Z życiem i działalnością polityczną biskupa krakowskiego Pawła z Przemankowa powiazane są rozmaite oskarżenia i pomówienia, które zostały zapisane w średniowiecznych źródłach narracyjnych. Część z nich stanowią zarzuty o charakterze politycznym, do których należy zaliczyć posądzenia biskupa o udział $\mathrm{w}$ buntach przeciw książętom krakowsko-sandomierskim oraz powiązania z najazdami litewskimi. Pozostałe zaś związane są z przywarami i usposobieniem Pawła z Przemankowa, przypisujące mu nikczemny charakter, prowadzenie rozpustnego życia, symonię czy też oskarżające go o zabójstwo.

Słowa kluczowe: biskupi krakowscy; księstwo krakowsko-sandomierskie; czarna legenda

\section{WPROWADZENIE}

Mąż nieokrzesany, światowy, przywiązany do dóbr ziemskich i rzadko odczuwający wyrzuty sumienia z powodu popełnionych występków ${ }^{1}$ - to tylko jedna z wielu opinii, jakie można znaleźć na temat biskupa krakowskiego Pawła z Przemankowa w średniowiecznych źródłach narracyjnych. Życie tego hierarchy kościelnego od lat budzi kontrowersje wśród badaczy. Jedni, w ślad za przekazami źródłowymi, uznawali go za niegodnego infuły, inni próbowali oczyścić go chociaż z części stawianych zarzutów. Przypadająca w tym roku 750. rocznica ob-

${ }^{1}$ Katalog Dlugosza, [w:] Monumenta Poloniae Historica (dalej: MPH), Series Nova (dalej: s.n.), t. 10, cz. 2, wyd. J. Szymański, Warszawa 1974, s. 181: Vir crudus, terrenus et mundatus, et qui super facinoribus grauibus raro conscientiae remorsu tangebatur. 
jęcia przez Pawła z Przemankowa katedry krakowskiej jest dobrą okazją, aby na nowo spojrzeć na czarną legendę, która powstała wokół jego osoby i podjąć trud odpowiedzi na pytanie, jakim człowiekiem był ów hierarcha kościelny. Informacje, jakie odnotowali kronikarze i rocznikarze o ordynariuszu krakowskim, można podzielić na dwie kategorie. Do pierwszej z nich zaliczyć należy wzmianki o działalności politycznej biskupa, drugą zaś stanowią opinie na temat charakteru Pawła oraz prowadzonego przezeń trybu życia. W niniejszych rozważaniach zostaną wykorzystane przekazy źródeł bliskich czasowo pontyfikatowi Pawła z Przemankowa, a także wyobrażenia o nim piętnastowiecznego historyka Jana Długosza.

\section{OCENA DZIAŁALNOŚCI POLITYCZNEJ PAWŁA Z PRZEMANKOWA}

Najwcześniejsze informacje o początkach kariery Pawła z Przemankowa sięgają 1253 r. Na liście świadków wystawionego przez biskupa Prandotę dokumentu wśród wikariuszy kapituły krakowskiej pojawia się Paulus submagister, którego historycy utożsamiają właśnie z osobą Pawła z Przemankowa². Występujący przy jego imieniu tytuł wskazuje, iż pełnił on wówczas funkcję nauczyciela w szkole katedralnej. Objęcie przez Pawła tego stanowiska pozwala przypuszczać, iż przed $1253 \mathrm{r}$. zdobył on wykształcenie uniwersyteckie w zakresie sztuk wyzwolonych i prawa kanonicznego, choć żadnych tytułów zapewne nie posiadł‥ Solidna edukacja otworzyła mu drzwi do kapituły krakowskiej oraz kancelarii Bolesława Wstydliwego, bowiem od czerwca 1263 r. występuje na dokumentach jako kanclerz oraz kanonik krakowski ${ }^{4}$. Objęcie jednego z najważniejszych urzę-

${ }^{2}$ M. Gładyszewicz (Żywot błogosławionego Prandoty z Białczowa biskupa krakowskiego, Kraków 1845, s. 254), F. Piekosiński (Rycerstwo polskie wieków średnich, t. 3, Kraków 1901, s. 134), J. Wyrozumski (Paweł z Przemankowa, [w:] Polski Stownik Biograficzny, t. 28: 1984-1985, s. 391) i A. Sochacka (Problemy genealogii Pótkozów Czyżowskich, [w:] Ludzie i herby w dawnej Polsce, red. P. Dymmel, Lublin 1995, s. 14) uznawali, że Paweł z Przemankowa jest tożsamy z Pawłem występującym w 1245 r. jako komornik biskupa Prandoty (Kodeks dyplomatyczny Wielkopolski [dalej: KDW], t. 1, wyd. 1, Zakrzewski, Poznań 1877, nr 244) oraz w 1250 r. jako jego kapelan i kanonik krakowski (Monografia opactwa cystersów we wsi Mogile, cz. 2: Zbiór dyplomów klasztoru mogilskiego [dalej: KMog], Kraków 1867, nr 23). Jednak ostatnio J. Maciejewski (Episkopat polski doby dzielnicowej 1180-1320, Kraków-Bydgoszcz 2008, s. 235) wykazał, że w rzeczywistości na listach świadków owych dokumentów występuje Paweł tożsamy z kapelanem biskupa Iwona z 1224 r. (Kodeks dyplomatyczny katedry krakowskiej św. Wacława [dalej: KDKK], t. 1, wyd. F. Piekosiński, Kraków 1874, nr 13-14), zaś Paweł z Przemankowa po raz pierwszy pojawia się w źródłach dopiero w $1253 \mathrm{r}$.

${ }^{3}$ K. Ożóg, Formacja intelektualna biskupów krakowskich w średniowieczu, [w:] Cracovia Polonia - Europa. Studia z dziejów średniowiecza ofiarowane Jerzemu Wyrozumskiemu w sześćdziesiąta piąta rocznicę urodzin i czterdziestolecie pracy naukowej, Kraków 1995, s. 167; M. Maciejowski, Orientacje polityczne biskupów metropolii gnieźnieńskiej 1283-1320, Kraków 2007, s. 58-59.

${ }^{4}$ Kodeks dyplomatyczny Małopolski (dalej: KDM), t. 1, wyd. F. Piekosiński, Kraków 1876, nr 66-67; KDM, t. 2, wyd. F. Piekosiński, Kraków 1886, nr 470-471; KDW, t. 1, nr 407; Codex diplomaticus Poloniae, t. 3, wyd. L. Rzyszczewski, A. Muczkowski, J. Bartoszewicz, Warszawa 1858, 
dów w księstwie krakowsko-sandomierskim niewątpliwie ułatwiło mu również awanse kościelne, ponieważ w 1266 r. występuje jako archidiakon sandomierski ${ }^{5}$, a 9 października 1266 r. został wybrany na biskupa krakowskiego ${ }^{6}$.

Mogłoby się wydawać, że Paweł z Przemankowa, który przed objęciem katedry krakowskiej sprawował urząd kanclerza Bolesława Wstydliwego, będzie po elekcji utrzymywał przyjazne stosunki z władcą. Tymczasem Rocznik Traski oraz Rocznik małopolski Szamotulskiego niemal jednogłośnie podają, że w 1273 r. pewni rycerze krakowscy, za radą biskupa krakowskiego Pawła, przeszli z całą swoją siłą na stronę księcia opolskiego Władysława. Bolesław jednak szybko zareagował na tę zdradę, wysyłając w pogoń za buntownikami wierne mu wojsko, któremu udało się zaskoczyć buntowników pod Bogucicami i pokonać ich po zaciętej bitwie ${ }^{7}$. Przekaz ten sugeruje zatem, że bunt przeciwko Bolesławowi Wstydliwemu wybuchł za radą biskupa. Według rocznikarzy był on nie tylko jednym z wielu buntowników, lecz głową rebelii, podżegającą rycerstwo do powołania na tron krakowski Władysława opolskiego.

Nieco ostrożniej do udziału ordynariusza krakowskiego w buncie podchodził Jan Długosz. Nie napisał bowiem wprost o związkach Pawła ze spiskowcami, lecz zaznaczył, iż ,jako jego głównego sprawcę obwiniano biskupa krakowskiego Pawła”, a w innym miejscu dodał, że „oskarżano go o rozlew krwi poległych w wojnie domowej pod Bogucinem" ". Na podstawie tych pogłosek podanych przez kronikarza niełatwo jest orzec, czy biskup rzeczywiście brał udział w rebelii, a jeśli tak, to w jakim stopniu był zaangażowany w działania buntowników. Nie wiadomo, czy był on głównym inicjatorem spisku czy może tylko po cichu błogosławił ich działaniom. Nieco więcej światła na związki Pawła z Przemankowa z rebelią rzuca Długosz w dalszym ciągu swojej narracji. Otóż buntownicy właśnie ,za radą i zachętą wymienionego biskupa krakowskiego Pawła ruszyli

nr 41. Według J. Wyrozumskiego (op. cit., s. 391) Paweł z Przemankowa objął urząd kanclerski na pewno po 9 maja 1262 r., kiedy to ostatni raz jest wspomniany kanclerz Przedpełk, i mógł go sprawować nawet aż do wyboru na biskupstwo, a więc do października 1266 r. Następca Pawła z Przemankowa na kanclerstwie krakowskim, Prokop, pojawia się na dokumentach dopiero 22 maja $1270 \mathrm{r}$. Zob. Urzędnicy matopolscy XII-XV wieku. Spisy, oprac. J. Kurtyka, T. Nowakowski, F. Sikora, A. Sochacka, P.K. Wojciechowski, B. Wyrozumska, red. A. Gąsiorowski, Wrocław 1990, nr 1201.

${ }^{5} \mathrm{KMog}, \mathrm{nr} 28$.

${ }^{6}$ Rocznik kapituły krakowskiej, [w:] MPH, s.n., t. 5, wyd. Z. Kozłowska-Budkowa, Warszawa 1978, s. 94.

${ }^{7}$ Rocznik Traski, [w:] MPH, t. 2, wyd. A. Bielowski, Lwów 1872, s. 842: Ipso anno quidam milites Cracovienses processerant ad ducem Opoliensem Wladyzlaum cum tota potencia sua de consilio episcopi Pauli Cracovie; Rocznik małopolski Szamotulskiego, [w:] MPH, t. 3, wyd. A. Bielowski, Lwów 1878, s. 175: Eodem anno quidam milites Cracovienses processavant ad ducem Wladislaum Opoliensem cum tota potencia sua de consilio Pauli episcopi Cracoviensis.

${ }^{8}$ J. Długosz, Roczniki, czyli Kroniki sławnego Królestwa Polskiego, ks. 7-8, przeł. J. Mrukówna, wyd. K. Pieradzka, Warszawa 1974, s. 230.

${ }^{9}$ Ibidem, s. 233. 
w wielkiej liczbie i niemal ze wszystkimi swoimi siłami i ludźmi” w stronę Opola, aby tam dopełnić formalności z księciem Władysławem. „Obawiali się bowiem ataku ze strony Bolesława Wstydliwego, ponieważ sprawa była bardzo głośna"10. Biskup krakowski jawi się zatem jako doradca spiskowców, który uważnie analizował bieżącą sytuację i zachęcał do szybszego działania. Jak się zresztą później okazało, jego obawy przed przedwczesnym starciem były w pełni uzasadnione. Czy sam wyruszył razem z rycerstwem i wspomagał je swoim ramieniem w krwawej bitwie pod Bogucinem, czy też może ograniczył się do wspierania radą tylko wówczas, kiedy buntownicy znajdowali się w pobliżu jego posiadłości - tego nie sposób rozstrzygnąć.

Cenną uwagę odnotował A. Semkowicz, który próbując bronić Pawła z Przemankowa, doszedł do wniosku, że trudno ocenić, ,czy wszyscy, którzy w tym rokoszu brali udział, zasługują na miano zdrajców, czy nie było głębszych motywów aniżeli te, które Długosz wyrozumował"'11. Warto zatem zastanowić się, czy któraś z przyczyn wybuchu buntu podawanych przez dziejopisa mogła zachęcić biskupa krakowskiego do poparcia, a może nawet przewodzenia rebelii.

Pierwszym z powodów, które według Jana Długosza miały kierować buntownikami, była kwestia sukcesji tronu po bezpotomnej śmierci Bolesława Wstydliwego. Rycerstwo krakowsko-sandomierskie miało zarzucać swojemu władcy, że „bez naradzania się z nimi i bez ich zgody przeznaczył na swego następcę niemiłego im księcia sieradzkiego Leszka Czarnego"12. Taka przyczyna wystąpienia przeciw Bolesławowi budzi jednak dużo wątpliwości. Ten sam kronikarz wspomniał bowiem pod rokiem 1265, iż książę krakowsko-sandomierski „specjalnym przywilejem i dokumentem ustanowił [Leszka] dziedzicem wszystkich swoich księstw i postanowił, że tylko on będzie po nim następcą we wszystkich jego ziemiach, księstwach i posiadłościach (wydawał się bowiem jemu i jego doradcom księciem o niezwykłych zaletach)"'13. O. Halecki, biorąc pod uwagę precyzyjnie podane szczegóły tego wydarzenia, a nawet powoływanie się Długosza na wystawiony wówczas dokument, uznał ową narrację jako rzecz wiarygodną ${ }^{14}$. $\mathrm{Z}$ tego założenia wyszedł także P. Żmudzki, który zwrócił uwagę, że adopcja, która funkcjonowała w polskim obyczaju prawnym, musiała dokonać się przy świadkach ${ }^{15}$. Zapewne więc i usynowienie Leszka Czarnego w 1265 r. musiało odbyć się za

${ }^{10}$ Ibidem, s. 231.

${ }^{11}$ A. Semkowicz, Rec. B. Ulanowski, Przyczynek do dziejów Pawła z Przemankowa, Kraków 1883, „Przegląd Powszechny” 1885, t. 6, s. 249.

12 J. Długosz, op. cit., ks. 7-8, s. 231.

${ }^{13}$ Ibidem, s. 185.

${ }^{14} \mathrm{O}$. Halecki, Powołanie księcia Władysława opolskiego na tron krakowski w r. 1273, „Kwartalnik Historyczny" 1913, R. 27, s. 259.

${ }^{15}$ Obyczaj ten nie był obcy Bolesławowi Wstydliwemu, bowiem sam został adoptowany w 1228 r. na wiecu w Cieni przez Władysława Laskonogiego. Zob. P. Żmudzki, Studium podzielonego królestwa. Ksiązę Leszek Czarny, Warszawa 2000, s. 191. 
zgodą dostojników krakowskich i sandomierskich. Wśród nich znajdował się najprawdopodobniej również ówczesny kanclerz księcia Bolesława, Paweł z Przemankowa. Zdaniem P. Żmudzkiego ci sami możni nie mieli powodu buntować się przeciw decyzji, którą sami podjęli 8 lat wcześniej ${ }^{16}$. Wydaje się, że sama adopcja księcia sieradzkiego nie mogła motywować biskupa krakowskiego do wystąpienia przeciw Bolesławowi Wstydliwemu. Możliwe jest nawet, że z racji sprawowanego wówczas urzędu Paweł mógł mieć jakiś wpływ na decyzję o usynowieniu Leszka Czarnego lub przynajmniej jej sprzyjał. Należy zwrócić uwagę, że książę sieradzki w $1271 \mathrm{r}$. zmienił swoją orientację polityczną z prowęgierskiej na proczeską, stając się sojusznikiem Przemysła Ottokara II w wojnie o spadek po Babenbergach. Jak zauważył P. Żmudzki, tym samym wypowiedział on przyjaźń Bolesławowi Wstydliwemu i przestał być jego następcą. W jego miejsce na najpoważniejszego kandydata do objęcia tronu krakowskiego po śmierci Bolesława Wstydliwego zaczął wyrastać Konrad II. Zdaniem P. Żmudzkiego bunt rycerstwa mógł być wyrazem sprzeciwu wobec tej kandydatury ${ }^{17}$.

Na kartach swoich Roczników Jan Długosz wylicza jeszcze więcej przyczyn, które, skumulowane, miały doprowadzić do wybuchu buntu w 1273 r. Zapisał on, iż w księstwie krakowsko-sandomierskim było wówczas ,wielu rycerzy, którzy żywili niechęć do Bolesława Wstydliwego, ponieważ niektórych z nich ukarał za ich występki konfiskatą dóbr dziedzicznych, innych skazał na śmierć, innych na trzymanie pod strażą"18. Zapewne karanie przestępców nie przyczyniłoby się do zbrojnego wystąpienia przeciw władcy. Jednak, jak informują źródła wcześniejsze od Długosza, książęce sądy niekoniecznie kończyły się sprawiedliwymi wyrokami. Spisana na Śląsku Kronika polska podaje, że Bolesława Wstydliwego można było przekupić nawet niewielkimi darami, a najłatwiej można było zyskać przychylność księcia, ofiarowując mu psy, których był wielkim miłośnikiem ${ }^{19}$. Jan Długosz, konstruując swoje opowiadanie o buncie z 1273 r., wykorzystał przekaz tego źródła i skrupulatnie przypisał księciu skłonność do przekupstwa oraz nieuczciwość w sądach ${ }^{20}$. Dodał przy tym krytykę zamiłowania Bolesława Wstydliwego do łowów, który ,jako myśliwy, polujący bez umiaru i względu na porę roku, wyrządzał raz po raz dotkliwe szkody tak duchow-

${ }^{16}$ P. Żmudzki, op. cit., s. 233. Częéś historyków przyjmowała za Długoszem adopcję Leszka Czarnego jako przyczynę wybuchu buntu w 1273 r. Zob. A. Semkowicz, Krytyczny rozbiór Dziejów polskich Jana Dlugosza (do roku 1384), Kraków 1887, s. 292-293; O. Halecki, op. cit., s. 257-259; R. Grodecki, Dzieje polityczne Śląska do r. 1290, [w:] Historia Śląska od najdawniejszych czasów do roku 1400, red. S. Kutrzeba, t. 1, Kraków 1933, s. 263.

${ }^{17}$ P. Żmudzki, op. cit., s. 233-234.

${ }^{18}$ J. Długosz, op. cit., ks. 7-8, s. 230-231.

${ }^{19}$ Chronica Polonorum, [w:] MPH, t. 3, s. 643: Cuius temporibus, licet calumpniarum virus per omnia loca sui principatus vigeret, modico munere tamen placatus, in partem quamlibet trahebatur, et maxime canum, quorum amator et fotor, toti terre importabilis fuit.

${ }^{20}$ A. Semkowicz, Krytyczny rozbiór..., s. 293. 
nym, jak świeckim. U wszystkich swoich poddanych, którzy byli w tym czasie obowiązani do udziału w łowach książęcych, a także do karmienia psów księcia, miał opinię uciążliwego i nieznośnego"21. Owa opinia o Bolesławie jest jednak niezgodna z tym, co Długosz pisał o tym władcy w innych miejscach. Pod rokiem 1248 odnotował bowiem, że ,zarówno u książąt polskich, jak i u sąsiednich narodów i królów dzięki swej prawości, gładkości obyczajów i niezwykłym zaletom charakteru zaczął uchodzić za wielkiego i sławnego"22. Natomiast opisując śmierć Bolesława, Długosz wspomina, co prawda, o jego zmienności przy rozstrzyganiu spraw oraz skłonnościach do przekupstwa, ale mimo to jest on tam ukazany jako cnotliwy książę i wielki dobrodziej Kościoła katolickiego. Ostatecznie według kronikarza władca ten „był człowiekiem dobrym i prostym, dalekim od wszelkiej obłudy"23.

Według P. Żmudzkiego negatywną opinię o Bolesławie Wstydliwym mogli przenieść na Śląsk pokonani buntownicy z 1273 r., przekazując tym samym informacje o motywach ich działania. Owo krytyczne zdanie o władcy Krakowa i Sandomierza miało być wyrazem niezadowolenia rycerstwa ze wzmacniania przez niego władzy książęcej. Ten plan książę realizował początkowo przez akcję lokacyjną miast, a następnie zaczął bezwzględnie egzekwować wyroki sądowe oraz regale łowieckie od rycerzy i chłopów ${ }^{24}$. Nic dziwnego, że Jan Długosz, według którego idealny władca powinien dzielić się swoją władzą z dostojnikami, korzystając z Kroniki polskiej, przejął z niej krytykę rządów Bolesława Wstydliwego ${ }^{25}$. Polityka konsolidacji władzy, prowadzona przez Bolesława, mogła nie podobać się również Pawłowi z Przemankowa. Bardzo prawdopodobne, że był on przeciwnikiem przeprowadzenia reformy gospodarki łowieckiej, ponieważ, jak pisał Długosz, biskup był „zajęty ciągle polowaniami po lasach”26. Być może z tego niezadowolenia skorzystali buntownicy i, zdobywszy sojusznika w osobie ordynariusza krakowskiego, wykorzystali jego autorytet do swoich działań ${ }^{27}$.

Jeśli zarzuty kronikarza co do nieuczciwości Bolesława Wstydliwego w sądach były prawdziwe, to również ten element mógł zachęcić Pawła z Przemankowa do poparcia rebelii. Z przekazu Rocznika kapitulnego krakowskiego wiadomo, że w 1271 r. miał miejsce bliżej nieokreślony zatarg między nim a parą książęcą, który udało się zażegnać w okresie Wielkiego Postu dzięki mediacji kanoni-

${ }^{21}$ J. Długosz, op. cit., ks. 7-8, s. 232. Według Jana Długosza zamiłowanie władcy do łowów było cechą negatywną, ponieważ odciągało go od zajmowania się sprawami państwowymi. Zob. M. Koczerska, Mentalność Jana Dlugosza w świetle jego twórczości, „Studia Źródłoznawcze” 1970, nr 15, s. 120.

\footnotetext{
${ }^{22}$ J. Długosz, op. cit., ks. 7-8, s. 77.

${ }^{23}$ Ibidem, s. 262-264.

${ }^{24}$ P. Żmudzki, op. cit., s. 234-235.

${ }^{25}$ Zob. M. Koczerska, op. cit., s. 121.

${ }^{26}$ J. Długosz, op. cit., ks. 7-8, s. 222-224.

${ }^{27}$ P. Żmudzki, op. cit., s. 235.
} 
ków krakowskich Dzierżykraja i Waltera ${ }^{28}$. Najprawdopodobniej mogło chodzić o jakieś sprawy finansowe, być może o dochody biskupa związane z akcją kolonizacyjną i lokacyjną ${ }^{29}$. Niewykluczone, że Paweł przekonał się wówczas osobiście o trudnościach dowodzenia swoich racji przed sądem książęcym i zniechęcił się do rządów Bolesława.

Większość historyków przyjmuje związek biskupa z buntownikami, podając jeszcze inne przyczyny zaangażowania się Pawła w wydarzenia roku 1273. B. Włodarski uważał, że poparcie udzielone przez ordynariusza krakowskiego rebeliantom było konsekwencją jego opowiedzenia się po czeskiej stronie w sporze o spadek po Babenbergach. Paweł z Przemankowa sprzyjał więc buntownikom, którzy w miejsce prowęgierskiego Bolesława Wstydliwego chcieli wprowadzić na tron krakowski Władysława opolskiego, a więc sojusznika Przemysła Ottokara $\mathrm{II}^{30}$. Jak słusznie zauważył J. Wyrozumski, taki pogląd nie ma dostatecznego poświadczenia w źródłach. Według niego częste występowanie biskupa w otoczeniu książęcym świadczy o lojalności wobec władcy. Jednak ,rozległy wówczas immunitet, jakim cieszył się Kościół polski, a także aspiracje duchowieństwa" mogły doprowadzić do różnych konfliktów w relacjach między dwo-

${ }^{28}$ Rocznik kapituly krakowskiej, s. 101: Dominus Paulus episcopus cum domine duce et eius coniuge domina ducissa discordat, et in quadragesima cum eisdem dominis magistro Dersycraio preposito et Walthero canonicis Cracoviensibus, viris constantibus, providis et discretis mediantibus concordavit.

${ }^{29}$ Zob. B. Ulanowski, Przyczynek do dziejów Pawła z Przemankowa, „Rozprawy i Sprawozdania z Posiedzeń Wydziału Historyczno-Filozoficznego Akademii Umiejętności” 1884, t. 17, s. 110; W. Karasiewicz, Pawet z Przemankowa biskup krakowski 1266-1292, „Nasza Przeszłość” 1959, t. 9, s. 173. O. Halecki (op. cit., s. 259), szukając przyczyn konfliktu biskupa z parą książęcą, przypuszczał, że mógł on być powiązany ze skargami ordynariusza wrocławskiego Tomasza na Bolesława Wstydliwego, jakie zanosił w listach do Pawła z Przemankowa i pozostałych biskupów metropolii gnieźnieńskiej. Dotyczyły one najazdów na Śląsk w 1271 r., związanych z czynnym uczestnictwem polskich książąt w walkach o spadek po Babenbergach. Wojska koalicji prowęgierskiej, do której przynależeli wówczas Bolesław Wstydliwy, Leszek Czarny i Konarad II mazowiecki, dokonały zniszczeń m.in. w majątkach biskupa wrocławskiego. Najazdy te przypadały jednak na okres od końca kwietnia do początku czerwca 1271 r., a więc już po zażegnaniu sporu biskupa Pawła z Bolesławem Wstydliwym i Kingą. Nie mogły zatem być przyczyną tego konfliktu. Zależności między nim a walkami o spadek po Babenbergach doszukiwał się również P. Żmudzki (op. cit., s. 232), według którego biskup krakowski sympatyzował z Czechami i Śląskiem, czego przykładem było propagowanie przez niego kultu św. Jadwigi w podległej mu diecezji. Odnowienie przez Bolesława Wstydliwego przymierza z królem węgierskim Stefanem V w 1270 r. miałby spowodować spór między dworem a kurią biskupią. Teza ta wydaje się być jednak słabo uargumentowana. Trudno bowiem z samego tylko popularyzowania kultu księżnej świętej wyciągać wnioski o prośląskiej i proczeskiej orientacji Pawła z Przemankowa. Znane są, co prawda, pisma Przemysła Ottokara II kierowane do poprzedniego biskupa krakowskiego, Prandoty, i stąd wiadomo o kontaktach kurii z dworem czeskim za czasów jego urzędowania (zob. B. Włodarski, Polityczna rola biskupów krakowskich w XIII wieku, „Nasza Przeszłość” 1967, t. 27, s. 48-49). Nie ma natomiast podobnych źródeł odnoszących się do pierwszych lat Pawła na katedrze krakowskiej.

${ }^{30}$ B. Włodarski, op. cit., s. 52. 
rem a kurią ${ }^{31}$. Natomiast zdaniem P. Żmudzkiego udział Pawła w buncie mógł być głosem solidarności z biskupem wrocławskim Tomaszem II, który bezskutecznie domagał się od Bolesława Wstydliwego odszkodowania za zniszczenia dokonane podczas najazdów w $1271 \mathrm{r}^{32}$

Jedynie W. Karasiewicz próbował udowodnić, że Paweł z Przemankowa nie miał nic wspólnego z rebelią w 1273 r. Doszedł on do wniosku, że autorzy Rocznika Traski i Rocznika małopolskiego Szamotulskiego, pisząc o buncie, korzystali z jednego źródła, które podawało poprawną wersję wydarzeń. Tymczasem kompilatorzy dokonali pewnej niewielkiej korekty, polegającej na dodaniu tylko jednego spójnika sed. Jeśli usunie się go z ich przekazu, wówczas trudno określić, czy Paweł z Przemankowa swoją radą służył buntownikom czy może Bolesławowi Wstydliwemu ${ }^{33}$. Kompilator dopasował je odpowiednio do czarnej legendy Pawła z Przemankowa, łącząc go tym samym z rebeliantami. W. Karasiewicz uważał jednak, że tym samym autorzy obu roczników popełnili błąd, czego potwierdzeniem ma być milczenie bliższych wydarzeniom źródeł o udziale Pawła w buncie przeciw Bolesławowi Wstydliwemu ${ }^{34}$. Koncepcja ta jest mało wiarygodna. Wynika ona z próby oczyszczenia biskupa krakowskiego ze wszystkich stawianych mu zarzutów, którą podjął w swojej pracy W. Karasiewicz. Aby ten cel osiągnąć, zignorował w tym przypadku jednoznaczny przekaz źródeł, chcąc je dostosować do swojej wizji Pawła z Przemankowa.

Raczej nie ma przesłanek, aby negować przekaz Rocznika Traski i Rocznika matopolskiego Szamotulskiego w sprawie udziału biskupa w buncie. Jest on jedyną osobą, którą źródła wprost łączą z tymi wydarzeniami. Co prawda, Długosz wspominał o ukaraniu buntowników przez Bolesława Wstydliwego konfiskatą mienia, ale wydaje się to być konsekwencją przekonań kronikarza, według którego każda zbrodnia powinna zostać odpowiednio ukarana ${ }^{35}$. Materiał dyplomatyczny nie dostarcza bowiem informacji o wyraźnych zmianach personalnych na urzędach księstwa krakowsko-sandomierskiego po 1273 r., jak będzie to miało miejsce po buncie z $1285 \mathrm{r}^{36} \mathrm{Z}$ jednej strony może to oznaczać, że przeciwników Bolesława Wstydliwego objęła szeroka amnestia. Z drugiej zaś może to

${ }^{31}$ J. Wyrozumski, op. cit., s. 392. O powiązaniach Pawła z Przemankowa z Czechami w pierwszych latach urzędowania na katedrze krakowskiej zob. przypis 28.

${ }^{32}$ P. Żmudzki, op. cit., s. 233.

${ }^{33}$ Po zabiegu proponowanym przez W. Karasiewicza zapiska rocznikarska brzmiałaby następująco: Ipso anno quidam milites Cracovienses processerant ad ducem Opoliensem Wladyzlaum cum tota potencia sua de consilio episcopi Pauli Cracovie Bolezlaus misso exercitu comprehendit eos in campo circa Boguczin, et comisso prelio forti occiderunt multi ex utraque parte quam plures.

${ }^{34}$ W. Karasiewicz, Pawet z Przemankowa..., s. 174-178.

${ }^{35}$ M. Koczerska, op. cit., s. 113.

${ }^{36}$ O. Halecki, op. cit., s. 271. Historycy domyślają się jedynie dwóch osób, które mogły przynależeć do buntu: Sułka Młodszego z Niedźwiedzia i kasztelana wiślickiego Dobiesława, syna Sąda z rodu Odrowążów. Zob. G. Klimecka, Ród potomków Sieciecha w wiekach XII-XIII, „Studia Źródłoznawcze" 1983, nr 28, s. 60; P. Żmudzki, op. cit., s. 235-236. 
świadczyć, że w rebelii nie uczestniczyli wysoko postawieni urzędnicy, lecz była ona inicjatywą mniej znaczącego rycerstwa ${ }^{37}$. Nie wiadomo też, czy jakiekolwiek konsekwencje za powiązania z buntownikami poniósł biskup krakowski.

W 1273 r. miało miejsce jeszcze jedno tragiczne dla księstwa krakowsko-sandomierskiego wydarzenie, które źródła narracyjne wiążą z knowaniami Pawła z Przemankowa. Jak podaje Rocznik Traski, biskupa posądzano o sprowadzenie najazdu litewskiego, który spowodował wielkie zniszczenia w ziemi lubelskiej ${ }^{38}$. Informację tę rozwinął w swoich Rocznikach Jan Długosz, według którego Litwinom miały towarzyszyć również posiłki Prusów i Żmudzinów. Ponieważ po stłumionym dopiero co buncie Bolesław Wstydliwy nie zdążył zebrać sił potrzebnych do odparcia najeźdźców, działali oni niemal bezkarnie, paląc wsie i uprowadzając licznych jeńców. Jak pisał Długosz:

[...] powszechnie było znane i szerzone podejrzenie, że także tę klęskę ściągnął biskup krakowski Paweł na swego wroga, księcia krakowskiego Bolesława oraz ziemię lubelską jakoby dla pomszczenia tych, którzy padli pod Boguszynem i że zarówno listownie, jak przez posłów podżegał powiązanych z nim bliskimi związkami Litwinów, z natury wrogów wiary [chrześcijańskiej] i Polaków, do wszczęcia wojny z Polakami i księstwami Bolesława Wstydliwego ${ }^{39}$.

Ze szczegółów, jakie podał Jan Długosz, wynika, że wyprawa ta miała charakter typowo łupieski ${ }^{40}$. Jak przypuszczał G. Błaszczyk, Litwini zapewne dowiedzieli się o wybuchu wojny domowej w Małopolsce i postanowili wykorzystać ją do własnych celów, choć nie wykluczył on, że inicjatywa najazdu mogła wyjść od buntowników. Pewną zachętą dla Litwinów mogła być również śmierć pod Bogucinem kasztelana łukowskiego Racibora, co niewątpliwie ułatwiło im drogę w głąb ziem polskich ${ }^{41}$.

W tym przypadku ani Rocznik Traski, ani Jan Długosz w swoich Rocznikach nie upierają się już przy tym, że najazd litewski był na pewno dziełem Pawła z Przemankowa. Wyraźnie zaznaczyli, że jest to tylko podejrzenie, którego nie mogli zweryfikować.

${ }^{37}$ Według P.K. Wojciechowskiego (Ugrupowania polityczne w ziemiach krakowskiej i sandomierskiej w latach 1280-1286, „Przegląd Historyczny” 1979, z 1, s. 68-69) jest mało prawdopodobne, żeby Bolesław Wstydliwy pozostawił na urzędach swoich przeciwników. Zdaje się więc to przemawiać za tą drugą możliwością.

${ }^{38}$ Rocznik Traski, s. 842: Eodem anno Lithwani miserabiliter devastaverunt terram Lublinensem [...] Imponebatur enim eidem, quod ipso [Paulus episcopus Cracoviensis] procurante fuisset facta strages supradicta in Lublin.

${ }^{39}$ J. Długosz, op. cit., ks. 7-8, s. 232-233.

${ }^{40}$ Zob. J. Powierski, Rola Jaćwieży $w$ walce ludów battyjskich z agresją krzyżacka, , ,Rocznik Białostocki” 1981-1982, nr 14, s. 105; G. Białuński, Studia z dziejów plemion pruskich i jaćwieskich, Olsztyn 1999, s. 114.

${ }^{41}$ G. Błaszczyk, Dzieje stosunków polsko-litewskich od czasów najdawniejszych do współczesności, t. 1: Trudne początki, Poznań 1998, s. 46-47. 
Według P. Żmudzkiego przypisanie biskupowi krakowskiemu sprowadzenia najazdu litewskiego na ziemię lubelską było spowodowane tym, że miał on miejsce w tym samym czasie, co bunt rycerstwa krakowskiego. Wzbudziło to podejrzenia co do rzeczowego związku obu wydarzeń. W konsekwencji zaczęły pojawiać się plotki o związkach Pawła z Przemankowa z Litwinami, rozpowszechniane może nawet przez sam dwór książęcy z zemsty za powiązania biskupa ze zbuntowanym rycerstwem ${ }^{42}$. Znalazły one odzwierciedlenie zarówno w IV i V redakcji Katalogu biskupów krakowskich ${ }^{43}$, jak i u Jana Długosza, według którego Paweł zaczął się porozumiewać ,z Litwinami i barbarzyńcami, których sobie zjednywał przez małżeństwa [sc. z członkami swej rodziny] i powinowactwo" ${ }^{44}$.

Związki biskupa krakowskiego z Litwinami są jednak rzeczą wątpliwą. Jak trafnie stwierdził W. Karasiewicz, sprowadzenie ich najazdów na terytorium księstwa krakowsko-sandomierskiego oznaczało również zniszczenie terenów jego własnej diecezji, a co za tym idzie zmniejszenie biskupich dochodów ${ }^{45}$. Byłoby to zatem bardzo nieracjonalne działanie. Ponadto, jak zauważył M. Maciejowski, sojusz dostojnika z poganami w ówczesnych realiach nie był możliwy do realizacji, ponieważ doprowadziłby do całkowitej izolacji biskupa ${ }^{46}$. Przeciwko współpracy Pawła z Przemankowa z Litwinami świadczy wreszcie wymowa dokumentów. W ugodzie zawartej między biskupem a Leszkiem Czarnym książę zobowiązał się do ochrony dóbr diecezji przed poganami ${ }^{47}$. Zdaniem M. Maciejowskiego, jeśliby Paweł rzeczywiście był sprzymierzony z Litwinami, to takiego zabezpieczenia by nie potrzebował. Skoro jednak o nie zabiegał, to widać sam się najazdów z ich strony obawia ${ }^{48}$.

${ }^{42}$ P. Żmudzki, op. cit., s. 236-237.

${ }^{43}$ Katalogi biskupów krakowskich. Redakcja IV świętokrzyska, [w:] MPH, s.n., t. 10, cz. 2, wyd. J. Szymański, Warszawa 1974, s. 64: Hic eciam cum Lithvanis connubia miscuit ut forcius resisteret suis aduersariis, quos plures habebat propter sua facinora; Katalogi biskupów krakowskich. Redakcja V dominikańska, [w:] MPH, t. 10, cz. 2, s. 99: Hic etiam cum Lithvanis connubia miscuit ut ferventius resisteret suis adversariis, quos plures habebat propter sua facinora. W. Karasiewicz (Pawet z Przemankowa ..., s. 188-189) przypuszczał, że informacja ta mogła znajdować się pierwotnie na marginesie zapiski o panowaniu Bolesława Wstydliwego. Książę ten rzeczywiście korzystał z pomocy Litwinów w wyprawie na księstwo wrocławskie w 1271 r. Natomiast kopista błędnie powiązał ją z osobą biskupa krakowskiego.

${ }^{44}$ J. Długosz, op. cit., ks. 7-8, s. 223. W swoim Katalogu biskupów krakowskich Jan Długosz precyzuje, że to cum duce Lithwanorum Stroÿnath ethnico et pagano connubia iungeret. Zob. Katalog Dlugosza, s. 179.

${ }^{45}$ W. Karasiewicz, Pawet z Przemankowa..., s. 189.

${ }^{46}$ M. Maciejowski, op. cit., s. 103.

${ }^{47} \mathrm{KDKK}, \mathrm{t} .1$, nr 85: Item prefatus dominus dux promisit propter Deum et suorem remissionem peccaminum, maxime in augmentum predicte satisfactionis quomodo gentilibus et paganis, cum volverint irruere super dijocesim Cracouiensem, resistet pro sua possibilitate, cum baronibus supradictis.

${ }^{48}$ M. Maciejowski, op. cit., s. 103. 
G. Błaszczyk nie wykluczał całkowicie tych kontaktów. Wprawdzie odrzucił tradycję mówiącą o związkach zawieranych z poganami w celach politycznych, ale przypuszczał, że mogły one świadczyć o planach jakiejś nieznanej misji chrystianizacyjnej ${ }^{49}$.

Oskarżenia Pawła z Przemankowa o sprowadzenie najazdu litewskiego na ziemię lubelską zaowocowały powstawaniem różnych plotek związanych z tymi wydarzeniami. Otóż, jak podają Rocznik Traski oraz Rocznik matopolski Szamotulskiego, po tych wydarzeniach biskup krakowski miał usłyszeć głos mówiący do niego: „Biada tobie biskupie Pawle, lepiej byłoby dla ciebie, abyś się nie narodził”. Słyszeć to miało ponad 70 mężów. Po pewnym czasie, kiedy Paweł z Przemankowa przebywał w podkrakowskim klasztorze dominikanów, tamtejsi bracia byli świadkami podobnego wydarzenia. Tym razem nieznany głos miał powiedzieć: „Nie bój się Pawle, czyń co chcesz, ponieważ ja jestem z tobą”. Wreszcie po raz trzeci został biskup nawiedzony przez ów głos, kiedy przebywał sam w swojej komnacie. Usłyszał wówczas: „Nie bój się Pawle, czyń co chcesz, ponieważ umrzesz siódmego roku". Na co ordynariusz krakowski odpowiedział: „Dobrze [...], ponieważ aż do siódmego roku mogę życie moje poprawić" ${ }^{50}$.

Jan Długosz, opisując w Rocznikach te niezwykłe wydarzenia, przedstawił je trochę inaczej. Według kronikarza owe głosy przemawiające do Pawła z Przemankowa były nie tylko konsekwencją oskarżeń o sprowadzenie najazdu pogan na ziemię lubelską, ale również obwiniania go o rozlew krwi pod Bogucinem. Długosz zmodyfikował też nieco historię o wizjach, które biskup miał mieć w swojej komnacie. Mianowicie:

[...] pewien zakonnik widział we śnie wilka z podniesionymi do góry przednimi łapami, wykrzykującego ludzkim głosem na biskupa Pawła: „Biada ci, biskupie Pawle, ponieważ grabiłeś i zabijałeś". Kiedy przerażony do głębi tym głosem i opinią, samotny wśród łez i lamentów opłakiwał swoje zbrodnie w komnacie, usłyszał drugi głos: „Nie bój się - biskupie Pawle! Czyń, co chcesz.

${ }^{49}$ G. Błaszczyk, op. cit., s. 46-47.

${ }^{50}$ Rocznik Traski, s. 842: Venit vox ad Paulum episcopum Cracoviensem dicens: Ve tibi, episcope Paule, melius tibi fuisset, si natus non fuisses. Hanc vocem audierunt bene 70 viri. Imponebatur enim eidem, quod ipso procurante fuisset facta strages supradicta in Lublin. Tandem post aliquantulum tempus venit vox dicens ei: Non timeas, Paule, fac quicquid volveris, quia ego tecum sum. Hanc audierunt multi fratres Predicatorum, in quorum domo eo tempore morabatur ante Cracoviam. Post aliquantulum vero tempus eodem anno predicto episcopo solo existente in cubiculo suo, venit vox de aëre dicens: Non timeas, Paule, fac quod vis, quia septimo anno morieris. Nec distinxit utrum septimo anno episcopatus sui vel septimo anno ab eo tempore, quo hec vox ad ipsum facta est. Ad quam vocem respondit episcopus: Bene, inquit, quia usque ad septimum annum potero vitam meam emendare. Et hanc vocem audierunt plures qui stabant ante cubiculum ipsius; Rocznik małopolski Szamotulskiego (s. 175) podaje legendę niemal identycznie. Jedyną znaczniejszą różnicą jest liczba mężów będących świadkami przyjścia do biskupa pierwszego głosu. Według Rocznika małopolskiego Szamotulskiego było ich około 60, a więc o 10 mniej, niż podaje Rocznik Traski. 
Za siedem lat masz umrzeć”. Na ten głos odpowiedział: „Boskie miłosierdzie najlepiej ze mną postąpi, jeśli mi przedłuży życie aż do siedmiu lat, bym przez ten czas mógł należycie odpokutować za popełnione przedtem występki”. Głosy te były tak donośne, że słyszeli je wyraźnie nawet ci, którzy pilnowali drzwi komnaty ${ }^{51}$.

Przepowiednia z zaświatów jednak się nie sprawdziła, ponieważ ordynariusz krakowski nie umarł ani w siódmym roku swojego urzędowania, ani w 7 lat od najazdu litewskiego na ziemię lubelską. Po usłyszeniu tajemniczych głosów żył jeszcze 19 lat. Według P. Żmudzkiego wszystkie te pogłoski o sprowadzeniu przez biskupa krakowskiego najazdu Litwinów były zwyczajnym obraźliwym pomówieniem, rozpowszechnianym być może przez sam dwór książęcy z zemsty za powiązania Pawła ze zbuntowanym rycerstwem. Do propagowania owych plotek przyczynili się także dominikanie krakowscy, rozpowiadając ową historię o rzekomych nawiedzeniach biskupa krakowskiego przez tajemniczy głos ${ }^{52}$.

Oskarżenia Pawła z Przemankowa o powiązania z najazdami litewskimi na księstwo krakowsko-sandomierskie pojawiają się ponownie na kartach Roczników pod rokiem 1283. Jak zapisał Jan Długosz, biskup był podejrzewany „o spowodowanie najazdu Litwinów dokonanego w tym i poprzednim roku"53. Zdaniem P. Żmudzkiego i tym razem owe pogłoski dotyczące kontaktów ordynariusza krakowskiego z poganami rozgłaszali dominikanie krakowscy. Sytuacja ku temu sprzyjała, bowiem najazd litewski wypadł na czas sporu o prawa do dominium sądeckiego, jaki toczył się między Leszkiem Czarnym a wdową po Bolesławie Wstydliwym - księżną Kingą. Biskup w konflikcie tym opowiedział się po stronie Kingi, przez co jego stosunki z księciem stały się wręcz wrogie ${ }^{54}$. Spór zakończył się ostatecznie dla Pawła z Przemankowa uwięzieniem w zamku sieradzkim na przełomie roku 1282/1283, o czym informuje Rocznik Traski ${ }^{55}$. Kiedy dopie-

${ }^{51}$ J. Długosz, op. cit., ks. 7-8, s. 233.

${ }^{52}$ P. Żmudzki, op. cit., s. 236-237.

${ }_{53}^{5}$ J. Długosz, op. cit., ks. 7-8, s. 286. Jak zauważył G. Błaszczyk (op. cit., s. 49), informacje Długosza o dwóch najazdach litewskich w latach 1282 i 1283 należy ze sobą połączyć. Litwini tylko raz wyprawili się na ziemie Leszka Czarnego, pustosząc Sandomierskie na przełomie września i października $1282 \mathrm{r}$.

${ }^{54}$ Według S. Gawlasa (O kształt zjednoczonego Królestwa, Warszawa 1996, s. 90) spór ten wywołało dążenie Leszka Czarnego do ograniczenia samodzielności władztwa księżnej Kingi w Sądecczyźnie. Jego zdaniem konflikt księcia z biskupem Pawłem miał mieć podobne przyczyny.

${ }^{55}$ Rocznik Traski, s. 849: Episcopus Cracoviensis dominus Paulus a duce Lestcone predicto in Lagow captivatur, ligatis omnibus artubus, Syradiensibus militibus in castrum Syradz transmillitur custodiendus. IV i V redakcja Katalogu biskupów krakowskich (MPH, n.s., t. 10, cz. 2), choć błędnie, umieszczają uwięzienie Pawła z Przemankowa w czasach Bolesława Wstydliwego oraz informują, iż za zamach na biskupa odpowiedzialni byli Otto i Żegota z Toporów. Biskup został uwolniony dopiero po interwencji papieża Marcina IV. Konflikt między Pawłem z Przemankowa a Leszkiem Czarnym zakończyła ugoda zawarta 8 grudnia 1284 r. Zob. B. Ulanowski, op. cit., s. 92-117; A. Rybarski, Udział Toporczyków w uwięzieniu biskupa krakowskiego, „Kwartalnik Historyczny” 
ro wkraczał on w decydującą fazę, dominikanie powrócili do pomówień z $1273 \mathrm{r}$. i wraz z dworem książęcym rozpowszechniali plotki o sprowadzeniu najazdu litewskiego przez skonfliktowanego z władcą biskupa. Owe legendy znalazły później odzwierciedlenie w V redakcji Katalogu biskupów krakowskich ${ }^{56}$. Źródło to rzeczywiście przypisuje Pawłowi z Przemankowa kontakty z Litwinami, ale nie podaje żadnych wskazówek chronologicznych, kiedy to miało miejsce ${ }^{57}$. Długosz, dysponując jego przekazem, mógł przypuszczać, iż współpraca biskupa z poganami miała miejsce przez cały okres jego zasiadania na katedrze krakowskiej. Skoro więc już raz mógł ściągnąć najazd swoich sprzymierzeńców w 1273 r., to zapewne był odpowiedzialny za kolejną ich wyprawę w $1282 \mathrm{r}$.

Pod tym samym rokiem źródła narracyjne przypisują Pawłowi z Przemankowa jeszcze jedną zdradę Leszka Czarnego. W Roczniku Traski odnotowano, iż wojewoda sandomierski Janusz wraz z tamtejszym rycerstwem wystąpili przeciw władcy krakowskiemu i wydali księciu mazowieckiemu Konradowi grody w Sandomierzu i Radomiu. Leszkowi Czarnemu udało się jednak wypędzić uzurpatora i stracone ziemie odzyskać w sposób pokojowy ${ }^{58}$. Przekaz ten wymienia tylko jednego przywódcę buntowników - wojewodę sandomierskiego Janusza. Rozbudowaną listę zdrajców przedstawia dopiero Jan Długosz. Według niego, oprócz wojewody, na czele rebelii stał również:

[...] kasztelan sandomierski Krystyn, z którymi podobno był w zmowie biskup krakowski Paweł. Ci, pragnąc od dawna zmian, sprowadzają do ziemi sandomierskiej stryjecznego brata Leszka Czarnego, księcia Mazowsza Konrada pod pozorem, że ów tak z tytułu prawa, jak i wieku uchodził za mającego większe od innych możliwości do objęcia następstwa po śmierci księcia krakowskiego i sandomierskiego Bolesława Wstydliwego i oddają mu w rzeczywiste posiadanie zarówno ziemię sandomierską i zawichojską, jak i resztę zamków i miast ziemi sandomierskiej.

Dalej Długosz dodaje, że Leszek, zgromadziwszy wojsko, wyruszył na ziemię sandomierską. Gdy dowiedział się o tym Konrad, nie dowierzając zbuntowanemu rycerstwu, wycofał się na Mazowsze. Księciu krakowskiemu udało się jednak na powrót pozyskać buntowników i bez oręża uśmierzył całą rebelięe ${ }^{59}$.

Część badaczy uwierzyła zapiskom rocznikarskim i opowiadaniu Jana Długosza. Uznali oni, iż rzeczywiście w 1282 r. miał miejsce bunt rycerstwa sando-

1912, t. 26, s. 1-12; W. Karasiewicz, Pawet z Przemankowa..., s. 193-213; B. Włodarski, op. cit., s. 53-55 ; P. Żmudzki, op. cit., s. 326-333.

${ }^{56}$ P. Żmudzki, op. cit., s. 325.

${ }^{57}$ Katalogi biskupów krakowskich. Redakcja V dominikańska, s. 99.

${ }_{58}$ Rocznik Traski, s. 848: Ianussius palatinus et milites Sandomirienses opposuerunt se predicto duci Lestkoni et castrum Sandomiriense et castrum de Radom tradiderunt duci Conrado, principi Mazowie; sed prefatus Lestko expulit Conradum de terra, et predicta castra et totam terram in pace possedit.

${ }_{59}$ J. Długosz, op. cit., ks. 7-8, s. 279-280. 
mierskiego przeciwko panowaniu Leszka Czarnego. Z racji zagrożenia najazdem litewskim książę jednak wybaczył rycerstwu udział w rebelii, a przywódcy buntu swoją zdradę odkupili zwycięstwem nad wrogiem ${ }^{60}$.

Ów udział $w$ bitwie $z$ Litwinami wojewody sandomierskiego Janusza ${ }^{61}$ wzbudził wątpliwości W. Karasiewicza co do wiarygodności informacji o buncie w 1282 r. Uznał on za niemożliwe, aby Leszek Czarny powierzył dowództwo jednego ze skrzydeł swojego wojska dygnitarzowi, który dopiero co miał wystąpić zbrojnie przeciwko władcy. Co więcej, prawdopodobnie na przełomie 1283 i 1284 r. Janusz objął kasztelanię krakowską ${ }^{62}$. Awans przywódcy buntu na najwyższy urząd w państwie też wydaje się być nieprawdopodobny. Niewiarygodność przekazów źródłowych na temat rebelii w 1282 r. wskazuje zatem na to, że jej po prostu nie było ${ }^{63}$.

$\mathrm{Z}$ takim rozumowaniem zgodził się w pełni P. Żmudzki. Według niego informacje, które podaje Rocznik Traski, należy odnieść do wydarzeń z 1285 r. Gdyby bowiem bezkrytycznie przyjmować przekaz tego źródła, trzeba by było przyjąć, iż miały miejsce aż cztery wystąpienia rycerstwa przeciw Leszkowi Czarnemu: jedno w 1282 r., dwa w 1285 r. i jedno w 1286 r. Ta mnogość informacji wydaje się być efektem pracy czternastowiecznego kompilatora, który może nie zweryfikował odpowiednio informacji odnoszących się w rzeczywistości do jednego wydarzenia $^{64}$. Za tym, że informacje o buncie w 1282 r. w rzeczywistości dotyczą

${ }^{60}$ A. Przeździecki, Paweł z Przemankowa. Rys historyczny z drugiej połowy XIII wieku w Polsce, nieznanych po większej części lub mało znanych źródeł skreślony, „Biblioteka Warszawska” 1851, t. 2, s. 21; O. Halecki, op. cit., s. 241; S. Krakowski, Obrona pogranicza wschodniego Matopolski za Leszka Czarnego, „Zeszyty Naukowe Uniwersytetu Lódzkiego. Nauki Humanistyczno-Społeczne" 1960, z. 15, s. 112. E. Marecki (Ugody księcia Leszka Czarnego z biskupem Pawtem z Przemankowa, „Studia Historyczne” 1986, z. 2, s. 265) przyczyn wybuchu zamieszek doszukiwał się w wystąpieniu Pawła z Przemankowa w obronie Kingi. Nieco ostrożniej do tego zagadnienia podszedł P.K. Wojciechowski (op. cit., s. 59), według którego księciu rzeczywiście groził bunt rycerstwa (a może nawet rozpoczęły się jakieś wstępne działania), jednak udało się go stłumić w zarodku.

${ }^{61} \mathrm{O}$ udziale w bitwie z Litwinami pod Równem wojewody sandomierskiego Janusza wspominają tylko te źródła, które podają również informacje o buncie w 1282 r., a więc Rocznik Traski (s. 848-849) oraz J. Długosz (op. cit., ks. 7-8, s. 282-285). Pozostałe roczniki, które odnotowują najazd litewski, milczą na temat dowódców. Zob. Rocznik franciszkański krakowski, [w:] MPH, t. 3, s. 51 oraz, pod błędnymi datami, Rocznik krakowski, [w:] MPH, t. 2, s. 849, Rocznik Sędziwoja, [w:] MPH, t. 2, s. 878 (1283 r.), Rocznik świętokrzyski, [w:] MPH, t. 3, s. 76 (1278 r.). Więcej o tych wydarzeniach zob. S. Krakowski, op. cit., s. 110-113; G. Błaszczyk, op. cit., s. 49; P. Żmudzki, op. cit., s. 304-307.

${ }^{62}$ Po raz ostatni Janusz występuje jako wojewoda sandomierski 10 sierpnia 1283 r., natomiast jako kasztelan krakowski został odnotowany po raz pierwszy 22 stycznia 1284 r. (jego poprzednik na tym urzędzie, Warsz, nie występuje na dokumentach już po 12 maja 1282 r.). Zob. Urzędnicy matopolscy..., nr 124, 967.

${ }^{63}$ W. Karasiewicz, Pawet z Przemankowa..., s. 204-205.

${ }^{64}$ P. Żmudzki, op. cit., s. 401-402. Według tego historyka istnieje jeden szczegół, który 
wydarzeń późniejszych, świadczyć może też relacja Jana Długosza o tym wydarzeniu, w której informuje o ucieczce Leszka Czarnego na Węgry ${ }^{65}$. Jak zauważył A. Semkowicz, szczegół ten odnosi się w rzeczywistości do rebelii z $1285 \mathrm{r}^{66}$ Można więc przypuszczać, że nie tylko ten fragment, lecz cały rozdział dotyczy wydarzeń późniejszych. Wydaje się wobec tego, że Paweł z Przemankowa nie mógł mieć nic wspólnego w 1282 r. z buntem przeciwko Leszkowi Czarnemu, ponieważ tak naprawdę żadnego wystąpienia zbrojnego przeciw władcy wówczas nie było.

Nie budzi natomiast żadnych zastrzeżeń wybuch rebelii przeciw władcy krakowsko-sandomierskiemu w 1285 r. Jak podaje Rocznik franciszkański krakow$s k i$, tego roku rycerstwo sprowadziło do ziemi krakowskiej i sandomierskiej księcia Konrada mazowieckiego, którego Leszek Czarny z pomocą niewielkiego oddziału Węgrów zatrzymał i zmusił do ucieczki. Wierni prawowitemu władcy pozostali jedynie niemieccy mieszczanie krakowscy, którym udało się obronić tamtejszy zamek ${ }^{67}$.

Więcej informacji o przebiegu buntu podają niemal jednakowo brzmiące przekazy Rocznika Traski i Rocznika małopolskiego Szamotulskiego. Wiadomo z nich, iż Leszek postanowił szukać pomocy na Węgrzech, zostawiwszy swoją żonę Gryfinę na zamku krakowskim obsadzonym przez mieszczan krakowskich. Z zadania, które powierzył im książę, krakowianie w pełni się wywiązali. Dzięki mężnej postawie mieszczan był to jedyny zamek w ziemi krakowskiej, który nie znalazł się w rękach buntowników ${ }^{68}$. Jak wskazuje na to zapiska Rocznika Sędziwoja, ich ducha nie złamało nawet spalenie miasta przez rebeliantów. Być może była to zemsta zbuntowanego rycerstwa za nieustępliwą postawę obrońców grodu na Wawelu. Do ostatecznego starcia między Leszkiem Czarnym a Konradem II

osłabia pewność, iż informacje z Rocznika Traski należy odnieść do 1285 r. Mianowicie źródło to podaje, że przywódca buntowników piastował godność wojewody sandomierskiego. Janusz Starża rzeczywiście w 1282 r. sprawował ten urząd, a trzy lata później był już kasztelanem krakowskim. P. Żmudzki thumaczy to jednak pomyłką rocznikarza. Jest to o tyle prawdopodobne, że wojewodą sandomierskim Janusz był przynajmniej 13 lat, podczas gdy godność kasztelana krakowskiego piastował tylko przez półtora roku. Rocznikarzowi zapadł zatem w pamięć ów dłużej sprawowany urząd. W 1285 r. wojewodą sandomierskim był inny Starża, Otton. Mogło więc dojść również do pomylenia Janusza z Ottonem.

${ }^{65}$ J. Długosz, op. cit., ks. 7-8, s. 280: „Niektórzy autorzy twierdzą, że książę Leszek Czarny z powodu buntu rycerzy uciekł na Węgry, wygnany przez sprawców buntu i że zabawiwszy tam jakiś czas, po pojednaniu, jakie nastąpiło między nim a rycerzami sandomierskimi, wrócił szczęśliwie do Krakowa z eskortą wojsk własnych i węgierskich".

${ }^{66}$ A. Semkowicz, Krytyczny rozbiór..., s. 300.

${ }^{67}$ Rocznik franciszkański krakowski, s. 51: Anno denique incarnacionis 1285 milites ducem Conradum Mazoviensem in terram Cracovie et Sandomirie adducunt, cui Lestko cum paucis Ungaris restitit et fugavit. Et quia theutonici cives Cracovienses tantummodo fideles fuerunt et castrum conservaverunt.

${ }^{68}$ Rocznik Traski, s. 851; Rocznik małopolski Szamotulskiego, s. 183-184. 
doszło pod Bogucicami ${ }^{69}$. Książę krakowski, któremu udało się na Węgrzech pozyskać pomoc ze strony tamtejszego rycerstwa, a nawet pogańskich Kumanów, dysponował niewielkimi siłami. Według Rocznika Traski i Rocznika małopolskiego Szamotulskiego jego wojsko, w skład którego poza posiłkami wchodzili wierni mu rycerze krakowscy, liczyło zaledwie 600 ludzi. Wystarczyło to jednak, aby zmusić księcia Konrada do ucieczki ${ }^{70}$.

Powyższe zapiski rocznikarskie nie podają, jak ustosunkował się do działań buntowników Paweł z Przemankowa. Jako pierwszy uczynił to dopiero Jan Długosz. Mianowicie według niego ,uknuli ten spisek jednomyślnie tak biskup krakowski Paweł, jak kasztelan krakowski Warsz oraz wojewoda krakowski Żegota, wojewoda sandomierski Janusz, kasztelan sandomierski Krystyn i pozostali możni i panowie ziemi krakowskiej i sandomierskiej”71. Owa lista zdrajców Leszka Czarnego przedstawiona przez kronikarza budzi zastrzeżenia. Jak zauważył A. Semkowicz, jedyną osobą, której kronikarz przypisał właściwe stanowisko, jest Żegota, który rzeczywiście był wówczas wojewodą krakowskim. Kasztelan krakowski Warsz po raz ostatni pojawia się w źródłach w 1279 r. W momencie wybuchu buntu urząd ten sprawował już Janusz Starża, którego na stanowisku wojewody sandomierskiego w 1284 r. zastąpił współrodowiec Otton. Wreszcie nie jest znany kasztelan sandomierski Krystyn, a godność tę od 1284 r. piastował $\mathrm{Marek}^{72}$. Owo błędne przypisanie urzędów według A. Semkowicza podważa wiarygodność całego opowiadania Długosza ${ }^{73}$.

O związkach owej czwórki dygnitarzy z powołaniem na tron krakowski księcia mazowieckiego Konrada II świadczy jednak materiał dyplomatyczny. Znane są dwa dokumenty, które bezpośrednio poświadczają udział w buncie wojewody sandomierskiego Ottona, za co spotkała go konfiskata majątków ${ }^{74}$. Z przywileju wystawionego przez Leszka Czarnego krakowskim dominikanom wiadomo rów-

${ }^{69}$ Rocznik Sędziwoja, s. 878.

${ }^{70}$ Rocznik Traski, s. 851; Rocznik małopolski Szamotulskiego, s. 183-184. Informacja o buncie rycerstwa pod rokiem 1285 odnotowana została również w: Roczniku małopolskim Kuropatnickiego, MPH, t. 3, wyd. A. Bielowski, Lwów 1878, s. 182; Roczniku krakowskim, MPH, t. 2, s. 851; Roczniku miechowskim, „Studia Źródłoznawcze”, t. 5, wyd. Z. Budkowa, 1960, s. 123. Są to jednak lakoniczne informacje, niepodające żadnych nowych szczegółów o przebiegu rebelii.

${ }^{71}$ J. Długosz, op. cit., ks. 7-8, s. 298.

${ }^{72}$ Kasztelan sandomierski Marek po raz ostatni występuje na dokumencie z sierpnia 1284 r., natomiast na dyplomie z 26 lutego 1286 r. urząd ten sprawuje już Mikołaj, syn Gniewomira. Zob. Urzędnicy małopolscy..., nr 742-743. Nie można zatem wykluczyć, że pomiędzy tymi dostojnikami kasztelanem sandomierskim był wymieniony przez Długosza Krystyn, który mógł stracić swój urząd za udział w buncie przeciwko Leszkowi Czarnemu lub zginąc pod Bogucicami.

${ }^{73}$ A. Semkowicz, Krytyczny rozbiór ..., s. 304-305.

749 stycznia 1286 r. Leszek Czarny nadał klaryskom skalskim wieś Żyrkowice, która niegdyś należała do owego urzędnika i została odebrana mu za udział w buncie (KDM, nr 110). Inną, należącą uprzednio do Starży, wieś, Wielogłowy, książę nadał 19 lutego 1287 r. komesowi Jerzemu, który dowodził posiłkami węgierskimi pomagającymi w stłumieniu rebelii (KDM, t. 1, nr 113). 
nież, że syn wojewody krakowskiego Żegoty, Grzegorz z Balic, jako winny obrazy majestatu, nie tylko wszystkie dobra, lecz i głowę utraci775. Informacja ta pozwala przypuszczać, że zdrady władcy mógł się dopuścić także ojciec skazańca. Poświadczać to zdaje się fakt, że zarówno on, jak i kasztelan krakowski Janusz znikają wówczas ze swoich urzędów, co może oznaczać, że zostali pozbawieni ich za związki z rebelią ${ }^{76}$. Na kasztelana jako przywódcę buntu wskazuje też Rocznik Traski, choć informacja ta została podana błędnie pod rokiem $1282^{77}$. Do zwolenników Konrada II mogli zaliczać się również kasztelanowie: sieciechowski Krystyn oraz sandomierski Marek Gryfita, bowiem i oni nie występują już w źródłach po bitwie pod Bogucicami. Być może właśnie pierwszego z nich miał na myśli Jan Długosz, wspominając o związkach ze spiskowcami kasztelana sandomierskiego Krystyna, ale przypisał mu błędny urząd ${ }^{78}$.

Jak wynika z powyższych zestawień, wszyscy czterej dygnitarze, którym Jan Długosz przypisywał przywództwo w buncie, choć wymienił ich na niewłaściwych urzędach, rzeczywiście mogli dopuścić się zdrady. W tym kontekście należy zastanowić się nad więzami łączącymi Pawła z Przemankowa z rebeliantami. Na kartach Roczników jest on wymieniony jako pierwszy ze spiskowców i to nie tylko ze względu na swoją godność. Jak zapisał Długosz, kiedy Konrad II podszedł pod Sandomierz, „wyszli mu naprzeciw biskup krakowski Paweł, który zamierzając pomścić przykrości swojego uwięzienia, wywołał tę burzę, oraz wszyscy pozostali panowie”. To właśnie ów hierarcha kościelny razem z innymi dostojnikami krakowskimi i sandomierskimi miał, według kronikarza, doradzać władcy mazowieckiemu wyruszenie na Kraków ${ }^{79}$. Skoro zatem udział w buncie pozostałych imiennie wymienionych w Rocznikach dostojników jest bardzo prawdopodobny, to czy również Paweł z Przemankowa rzeczywiście wystąpił przeciw rządom Leszka Czarnego?

${ }^{75}$ KDKK, t. 1 , nr 86.

${ }^{76}$ Żegota jako wojewoda sandomierski ostatni raz występuje 19 lutego 1284 r., a 9 czerwca 1285 r. urząd ten sprawował już Piotr, syn Bogumiła. Natomiast Janusz kasztelanem krakowskim był jeszcze w $1285 \mathrm{r}$. (dokument bez daty dziennej), a jego następca na tym dygnitarstwie pojawia się 9 czerwca tego roku. Urzędnicy małopolscy..., nr 124-125, 452-453. Zarówno Otton, jak i Żegota powrócili do księstwa krakowsko-sandomierskiego dopiero po śmierci Leszka Czarnego. Janusz po $1285 \mathrm{r}$. nie pojawia się już na dokumentach - być może podzielił los Grzegorza z Balic i za udział w buncie zapłacił głową lub zginął w bitwie pod Bogucicami. Zob. P. Żmudzki, op. cit., s. 406-407.

${ }^{77}$ Rocznik Traski, s. 848. Kasztelan krakowski Janusz występuje po raz ostatni na swoim urzędzie na dokumencie z 1285 r. (bez dokładnej daty), zaś wojewoda krakowski Żegota - 19 lutego 1284 r. Zob. Urzędnicy małopolscy..., nr 124, 452.

${ }^{78}$ Urzędnicy matopolscy..., $\mathrm{nr} 742,1059$. O innych potencjalnych uczestnikach buntu zob. P.K. Wojciechowski, op. cit., s. 62-66; P. Żmudzki, op. cit., s. 406-408.

79 J. Długosz, op. cit., ks. 7-8, s. 289-299. 
Jak zauważył A. Przeździecki, choć nie wspominają o tym źródła współczesne wydarzeniom, to nawet owo milczenie świadczy przeciwko niewinności biskupa krakowskiego. Skoro nie ma żadnych informacji, że w czasie, gdy od Leszka Czarnego odstąpiło niemal całe rycerstwo, Paweł razem z Gryfiną bronił grodu wawelskiego, to oznacza, iż zaszył się on w swojej ulubionej puszczy kieleckiej, by tam „oczekiwać skutków knowanej zdrady”"

Także O. Halecki opowiedział się za udziałem biskupa w buncie, o czym według badacza ma świadczyć nowa umowa zawarta przez niego z Leszkiem Czarnym w $1286 \mathrm{r}$. Nie wspomina ona nic o dawniejszym porozumieniu i na tej podstawie Halecki uznał, że musiało być ono zerwane przez wydarzenia $1285 \mathrm{r}^{81}$

W obronie związków ordynariusza krakowskiego z buntownikami stanął też niedawno W. Bielak. Uznał on, że udział Pawła z Przemankowa w rebelii nie musiał oznaczać jego inspiratorskiej i przywódczej roli. Co prawda, Długosz przedstawia go jako głowę całego przedsięwzięcia, lecz mógł przy tym wyolbrzymić rolę, jaką biskup odegrał w buncie. Hierarcha Kościoła krakowskiego mógł natomiast udzielić zdrajcom moralnego czy ideologicznego wsparcia lub przynajmniej opowiedzieć się po ich stronie, a nie musiał tego robić w sposób manifestacyjny. W końcu Jan Długosz „nie był bajkopisarzem” i musiał dysponować przynajmniej jakąś nieprzychylną Pawłowi z Przemankowa tradycją. Według W. Bielaka również zawarta w 1284 r. ugoda nie wyklucza udziału Pawła w buncie, ponieważ dotyczyła ona innych kwestii. W przypadku zwycięstwa Konrada czerskiego mógł on natomiast liczyć na wdzięczność nowego władcy. Historyk ten zauważył także, że wobec tak istotnego wydarzenia, jakim było wystąpienie rycerstwa przeciw władcy, biskup nie mógł pozostać neutralny. Przedstawione w ugodzie z 1286 r. przyczyny konfliktu ordynariusza krakowskiego z Leszkiem Czarnym (została ona zawarta post fomitem odiorum, post inimiciciarum seminaria, et post discordiarum discrimina ${ }^{82}$ ), z racji różnych możliwości ich przetłumaczenia, nie muszą świadczyć o jego neutralności wobec buntu. Jak spostrzegł, odium to nienawiść, inimiticia oznacza wszelkie działania nieprzyjacielskie, walki rodów i zemstę, a discordia - niezgodę, spór i knowania polityczne ${ }^{83}$.

W. Bielak w swoich badaniach ograniczył się wyłącznie do obrazu biskupa wyłaniającego się z zapisów kronikarskich i stąd po części doszedł do takich, a nie innych wniosków. Gdyby jednak prześledził opis wydarzeń 1285 r., który podają polskie roczniki, nie mógłby nie zauważyć, że żadne inne źródło poza Długoszem nie potwierdza powiązań Pawła z Przemankowa z buntownikami. Wydaje się, że tradycję łączącą osobę biskupa krakowskiego z wystąpieniem przeciw

\footnotetext{
${ }^{80}$ A. Przeździecki, op. cit., s. 37.

${ }^{81}$ O. Halecki, op. cit., s. 245.

${ }^{82}$ KDKK, t. 1 , nr 88.

${ }^{83}$ W. Bielak, Biskup i jego urząd w oczach średniowiecznych kronikarzy polskich, Lublin 2011, s. $215-216$.
} 
władcy kronikarz mógł zaczerpnąć jedynie z zapisek dotyczących buntu przeciwko Bolesławowi Wstydliwemu z 1273 r. Być może właśnie one posłużyły mu do przypisania Pawłowi również zdrady księcia Leszka Czarnego. Skoro bowiem biskup był zamieszany w rebelię z lat 70., to mógł też wziąć udział w podobnych wydarzeniach dekadę później, zwłaszcza że z ówczesnym księciem był rzeczywiście skonfliktowany.

Opierając się właśnie na milczeniu źródeł o udziale Pawła z Przemankowa w rebelii, A. Semkowicz doszedł do przekonania, że przedstawienie biskupa krakowskiego jako głównego inicjatora buntu jest domysłem własnym J. Długosza. Zauważył on, iż rzekoma przyczyna, która miała kierować postępowaniem biskupa, a więc chęć zemsty za uwięzienie go w sieradzkim zamku, była spowodowana nieznajomością przez kronikarza dokumentu ugody z grudnia 1284 r. Porozumienie to było bardzo korzystne dla ordynariusza krakowskiego i musiało usunąć jego urazę do Leszka Czarnego ${ }^{84}$. A. Semkowicz spostrzegł także, że biskup znajduje się na liście świadków dokumentu Leszka Czarnego, wystawionego 9 czerwca 1285 r. w Krakowie, w którym książę potępił zdrajców, a wynagrodził wiernego mu rycerza Stanisława z Chrobrza ${ }^{85}$. Jeśli Paweł byłby zamieszany w rebelię, to jego obecność w otoczeniu władcy byłaby niemożliwa. Jako główny inspirator buntu musiałby zapewne liczyć się z poważnymi konsekwencjami, przynajmniej na miarę tych, które stały się udziałem Ottona Starży, przywódcy rebeliantów. Skoro zatem Pawła z Przemankowa nie dotknęły żadne kary, przypisywanie mu odpowiedzialności za wystąpienie rycerstwa sandomierskiego nie ma żadnych podstaw ${ }^{86}$.

W. Karasiewicz, wdając się w polemikę z O. Haleckim, doszedł do przekonania, że druga ugoda zawarta między ordynariuszem krakowskim a Lesz-

${ }^{84}$ KDKK, t. 1, nr 85. W ugodzie tej Leszek Czarny zobowiązał się, w ramach rekompensaty za uwięzienie i wszelkie krzywdy wyrządzone Pawłowi z Przemankowa, w ciągu 6 najbliższych lat wypłacić 6000 grzywien srebra. Za połowę tej sumy książę oddał biskupowi miasto Korczyn ze wszystkimi prawami, jurysdykcją i dochodami, które w jego posiadaniu miało pozostać do czasu spłacenia owych 3000 grzywien. Jeśli jednak władca w ciągu 1285 r. zapłaciłby 1000 grzywien, wówczas mógłby wymienić Korczyn na inne dobra, odpowiadające równowartości zastawu za 2000 grzywien. Wszystkie dochody wynikające z faktu posiadania Korczyna przez Pawła miały być zaliczone na rzecz odszkodowania. Leszek Czarny podarował biskupowi również część wsi Dzierążnia o nazwie Konary ze wszystkimi jej mieszkańcami, którzy przez 3 lata mieli służyć Pawłowi tak, jak dotąd wykonywali swoje zobowiązania względem księcia. Za pozostałe 3000 grzywien srebra poręczyć mieli swoim majątkiem ruchomym i nieruchomym wyznaczeni do tego dostojnicy, kasztelanowie: krakowski Janusz, sandomierski Marek, wiślicki Sułek, lubelski Jan, radomski Piotrek, wojnicki Świętosław oraz wojewoda sandomierski Otton. Książę Leszek zobowiązał się także bronić wraz ze swoimi baronami diecezji krakowskiej przed najazdami pogan.

${ }^{85} \mathrm{KDM}$, t. 1 , nr 109.

${ }^{86}$ A. Semkowicz, Rec. B. Ulanowski, Przyczynek do dziejów Pawła z Przemankowa..., 1885, s. 249-250; idem, Krytyczny rozbiór..., s. 305. 
kiem Czarnym 30 listopada 1286 r. wcale nie wskazuje na udział Pawła w buncie 1285 r. Wręcz przeciwnie, wynika z niej, że to książę jest krzywdzicielem, natomiast biskup jest stroną pokrzywdzoną. Również termin zawarcia porozumienia półtora roku po uśmierzeniu buntu świadczy przeciwko związkom Pawła z Przemankowa z rebelią ${ }^{87}$.

Najkorzystniejsza dla biskupa krakowskiego wydaje się jednak hipoteza przedstawiona przez P. Żmudzkiego. Uznał on, że w owym zjeździe, który odbył się 9 czerwca 1285 r. w Krakowie, uczestniczyli najbliżsi współpracownicy Leszka Czarnego. Obecność biskupa na liście świadków wystawionego wówczas dokumentu przemawia za wnioskiem, że i on się do nich zaliczał. P. Żmudzki przypuszczał nawet, że w momencie wybuchu buntu biskup krakowski jednoznacznie opowiedział się po stronie prawowitego władcy i prawdopodobnie razem z księżną Gryfiną oraz mieszczanami krakowskimi bronił grodu wawelskiego przed atakami zbuntowanego rycerstwa ${ }^{88}$. Domysły te potwierdzają spostrzeżenie W. Bielaka, że pasterz Kościoła krakowskiego nie mógł pozostać neutralny względem buntu rycerstwa. W odróżnieniu od niego P. Żmudzki uznał, że Paweł z Przemankowa nie udzielał po cichu swojego błogosławieństwa rebeliantom, lecz jawnie opowiedział się po stronie Leszka Czarnego.

Przeciwko relacji Długosza, który umieścił ordynariusza krakowskiego wśród inicjatorów buntu, wydaje się też świadczyć podawana przez niego przyczyna wystąpienia rycerstwa krakowsko-sandomierskiego, iż to właśnie biskup ,wywołał tę burzę" w ramach zemsty za swoje uwięzienie. Czy ordynariusz krakowski, kierując się takimi pobudkami, sprzymierzyłby się z Ottonem i Żegotą z Toporów, a więc ludźmi, którzy prawdopodobnie odpowiadali za zamach na jego osobę? ${ }^{89}$ Jak zauważył J. Wyrozumski, wydaje się to być mało realne ${ }^{90}$. Zresztą, czy osobiste urazy jednej osoby, w dodatku mającej licznych wrogów wśród możnowładców, mogły przyczynić się do otwartego buntu przeciw panowaniu w Krakowie i Sandomierzu Leszka Czarnego? Raczej za wybuchem rebelii musiały stać znacznie poważniejsze powody. Według R. Trawki do konfliktów między władcą a społeczeństwem dochodziło, gdy interesy obu stron krzyżowały się ze sobą. Jeśli książę nie zaspokajał potrzeb swoich ludzi i nie liczył się z ich wolą, wówczas

${ }^{87}$ W. Karasiewicz, Pawet z Przemankowa..., s. 223-224.

${ }^{88}$ P. Żmudzki, op. cit., s. 436.

${ }^{89}$ Zob. przypis 55. Porwanie Pawła z Przemankowa przez Ottona i Żegotę stanowiło element tradycji rodowej Toporów. Zob. J. Kurtyka, Elita małopolska XIII i XIV w. - przerwa czy kontynuacja (na przykładzie Toporów: potomstwo Żegoty wojewody i kasztelana krakowskiego), [w:] Genealogia. Polska elita polityczna $w$ wiekach średnich na tle porównawczym, red. J. Wroniszewski, Toruń 1993, s. 38-39; idem, Tęczyńscy. Studium z dziejów polskiej elity możnowładczej w średniowieczu, Kraków 1997, s. 36.

${ }^{90}$ J. Wyrozumski, op. cit., s. 393. 
czekał go bunt ${ }^{91}$. Zapewne więc rokosz z 1285 r. musiał mieć podłoże w niezadowoleniu poddanych z prowadzonej przez Leszka Czarnego polityki ${ }^{92}$. Nie mógł raczej narzekać na nią po 1284 r. Paweł z Przemankowa, który dostał odpowiednie zadośćuczynienie za krzywdy wyrządzone mu przez księcia, odtąd już blisko współpracującego z Kościołem. Jeśli zatem biskup rzeczywiście opowiedział się po stronie władcy, dzięki swej postawie mógł spodziewać się zacieśnienia współpracy z księciem. Być może pierwszym krokiem do osiągnięcia tego celu było zawarcie 30 listopada 1286 r. kolejnej ugody między władcą a biskupem krakowskim $^{93}$. Odtąd bowiem najwyższą władzę świecką i duchowną w księstwie krakowsko-sandomierskim połączyła niczym niezmącona współpraca ${ }^{94}$.

Sytuacja zmieniła się wraz ze śmiercią Leszka Czarnego. Kandydatów do objęcia tronu początkowo było trzech: Bolesław płocki, Konrad czerski oraz Henryk IV Probus. Rocznik Traski oraz Rocznik Sędziwoja pod 1288 r. podają informację, iż po śmierci władcy krakowsko-sandomiersko-sieradzkiego jego następcą, w wyniku elekcji, został książę mazowiecki Bolesław ${ }^{95}$. Nieco więcej szczegółów dotyczących wyboru nowego księcia podaje Kroniczka krakowska (dawniej zwa-

${ }^{91}$ R. Trawka, Instrumenty oddziaływania społeczeństwa na władcę $w$ średniowieczu w Polsce Piastów do końca XIII w., ,Rocznik Muzeum w Gliwicach” 1991/1992, t. 7/8, s. 36.

${ }^{2} \mathrm{O}$ przyczynach wybuchu buntu przeciw Leszkowi Czarnemu zob. P.K. Wojciechowski, op. cit., s. 69; G. Klimecka, op. cit., s. 61-62; P. Żmudzki, op. cit., s. 409-411.

${ }^{93} \mathrm{KDKK}, \mathrm{t} .1$, nr 88. Zgodnie z jej postanowieniami książę na rzecz odszkodowania powinien zapłacić 3000 grzywien srebra oraz podarować biskupowi wieś Dzierążnię wraz z ludźmi książęcymi i wszelkimi wolnościami. Ponadto Leszek Czarny miał nadać kasztelanii piątkowskiej immunitet, jaki obowiązywał w innych wsiach należących do kapituły krakowskiej, potwierdzić przywileje, które Bolesław Wstydliwy nadał znajdującej się w posiadaniu biskupa kasztelanii sławkowskiej, a także zaprzysiąc, iż biskupa i Kościół krakowski otoczy synowską miłością. Paweł z Przemankowa, całkowicie zadowolony z wyniku rozmów, darował księciu zapłacenie owych 3000 grzywien srebra. W historiografii przeważa pogląd, że przyczyną zawarcia nowej ugody było niedotrzymanie umowy z 1284 r. przez Leszka Czarnego, który był niechętny każdemu ograniczeniu swojej władzy książęcej. Zob. A. Przeździecki, op. cit., s. 33; O. Halecki, op. cit., s. 245 W. Karasiewicz, Pawet z Przemankowa..., s. 221; B. Włodarski, op. cit., s. 55; E. Marecki, op. cit., s. 267; J. Wyrozumski, op. cit., s. 393; P. Żmudzki, op. cit., s. 437, 439.

94 P. Żmudzki (op. cit., s. 439-440), na podstawie zamieszczonego w dokumencie zwrotu o reipublice propagacio, domyślał się, iż mogło chodzić nawet o jakieś dalekosiężne plany snute przez księcia i biskupa. W praktyce ich współpraca przejawiała się w prowadzeniu wspólnej polityki w odniesieniu do trwającego na Śląsku konfliktu pomiędzy księciem Henrykiem IV a biskupem Tomaszem II. Leszek Czarny wspierał również Pawła z Przemankowa, wydając korzystne dla niego wyroki sądowe.

${ }^{95}$ Rocznik Traski, s. 852: Lestco dux Cracovie, Sandomirie, Syradie sine prole obiit, cui Bolezlaus, dux Mazovie, succedit per eleccionem; Rocznik Sędziwoja, s. 878: Lesthko dux Cracovie, Sendomirie et Syradie obiit sine prole. Cui Boleslaus dux Mosovie succedit per electionem. O wyborze Bolesława informuje również Rocznik małopolski Kuropatnickiego, [w:] MPH, t. 3, s. 184-185 pod 1290 r.: Mortuo Leskone sine prole, Boleslaus succedit dux Mazovie electus a militibus, a także Rocznik małopolski Gesselena ([w:] MPH, t. 3) pod 1322 r.: Lystko obiit absque liberis. Boleslaus post eum dux Masovia princibat. 
na Rocznikiem kujawskim), która precyzuje, że owego wyboru w 1289 r. dokonała szlachta krakowska i sandomierska ${ }^{96}$. Z przekazów rocznikarskich wynika zatem, że po śmierci Leszka Czarnego zebrało się rycerstwo krakowsko-sandomierskie i na drodze elekcji wybrało na swego władcę księcia mazowieckiego Bolesława. Źródła rocznikarskie nie wspominają jednak nic o udziale Pawła z Przemankowa w wyborze nowego władcy. Dopiero Jan Długosz, opisując te wydarzenia, dodał, że elekcja odbyła się na zjeździe w Sandomierzu, którego inicjatorem był Paweł z Przemankowa ${ }^{97}$. Nie wiadomo, czy kronikarz zaczerpnął te informacje z jakiegoś nieznanego źródła czy też są one jego własnym domysłem. Według T. Nowakowskiego przynajmniej osoba przywódcy rycerstwa krakowsko-sandomierskiego, a więc Pawła z Przemankowa, wydaje się być bardzo prawdopodobna. Przypuszczał on, że biskup krakowski mógł być upoważniony do zwoływania wiecu elekcyjnego oraz przewodniczenia jego obradom. Podobną rolę miał on jeszcze odegrać w 1291 r. podczas pertraktacji z Wacławem II ${ }^{98}$.

Przywódcza rola na zjeździe sandomierskim, jaką przypisał Pawłowi z Przemankowa Długosz, pozwala widzieć w nim głównego zwolennika Bolesława płockiego ${ }^{99}$. Jak zauważył A. Semkowicz, biskup reprezentował ideę wolnego wyboru władcy spośród najmłodszej linii piastowskiej i mógł liczyć na poparcie prawie całego rycerstwa krakowskiego ${ }^{100}$. Dlaczego Paweł opowiedział się właśnie za tym kandydatem? A. Semkowicz domyśla się, że po księciu ożenionym z córką księcia litewskiego Trojdena spodziewano się, że obroni on ziemie polskie przed najazdami litewskimi ${ }^{101}$. Zdaniem T. Nowakowskiego do wyboru Bolesława przyczyniły się również inne względy natury politycznej. Na poparcie biskupa nie mógł liczyć Konrad czerski, ponieważ jego głównymi zwolenni-

\footnotetext{
${ }^{96}$ Rocznik kujawski, [w:] MPH, t. 3, s. 207: Anno domini 1289 Lestkone Nigro vita functo terrigene Cracovie et Sandomirie assumpserunt Boleslaum ducem Mazovie in principem sibi.

${ }^{97}$ J. Długosz, op. cit., ks. 7-8, s. 322.

${ }_{98}$ T. Nowakowski, Małopolska elita władzy wobec rywalizacji o tron krakowski $w$ latach 1288-1306, Bydgoszcz 1992, s. 16.

${ }^{99}$ Za przywódcę stronnictwa popierającego Bolesława płockiego uznali Pawła z Przemankowa: A. Semkowicz, Walka o monarchia 1288-1294 (ustęp z dziejów piastowskich), „Kwartalnik Historyczny" 1891, R. 5, s. 729; S. Sobaniec, Zabiegi Henryka IV Wrocławskiego o Kraków i jego usiłowania odnowienia Królestwa, [w:] Księga pamiatkowa ku czci Oskara Haleckiego, Warszawa 1935, s. 235; J. Tęgowski, Zabiegi księcia kujawskiego Wtadysława Łokietka o tron krakowski w latach 1288-1293, „Zapiski Kujawsko-Dobrzyńskie. Historia” 1988, t. 6, s. 50; T. Nowakowski, op. cit., s. 16; A. Teterycz-Puzio, Małopolska elita władzy wobec zamieszek politycznych w Matopolsce w XIII wieku, ,Społeczeństwo Polski Średniowiecznej” 2001, t. 9, s. 81. Według B. Włodarskiego (op. cit., s. 56) kandydaturę Bolesława płockiego poparł nie tylko Paweł z Przemankowa, ale także arcybiskup gnieźnieński Jakub Świnka. Obaj byli przeciwni ubiegającemu się również o tron krakowski Henrykowi IV Probusowi z powodu konfliktu, jaki ten książę toczył z biskupem wrocławskim Tomaszem.

${ }^{100}$ A. Semkowicz, Walka o monarchiq ..., s. 729.
${ }^{101}$ Ibidem, s. $730-731$.
} 
kami byli przedstawiciele rodu Toporów, a więc osobiści wrogowie ordynariusza krakowskiego. Także kandydatura Henryka IV nie mogła odpowiadać Pawłowi z Przemankowa, gdyż władca ten zajmował dotąd nieustępliwe stanowisko wobec Kościoła. Natomiast za Bolesławem mógł przemawiać fakt, że był wnukiem Kazimierza Sprawiedliwego i miał z tej racji prawa dziedziczne do tronu krakowskiego $^{102}$.

Jest bardzo prawdopodobne, iż po wycofaniu się Bolesława płockiego z rywalizacji o spadek po Leszku Czarnym, Paweł z Przemankowa przeszedł wraz z innymi zwolennikami księcia mazowieckiego do obozu Władysława Łokiet$\mathrm{ka}^{103}$. Niewątpliwie nie poparł on w walkach o Kraków kandydata, który wyszedł z nich zwycięski, czyli Henryka Probusa. Konsekwencje swych wyborów politycznych biskup odczuł bardzo dotkliwie. Jak podają Rocznik Traski, Rocznik Sędziwoja i Rocznik małopolski Szamotulskiego, ordynariusz krakowski został uwięziony ${ }^{104}$. Rocznik krakowski precyzuje, że dokonali tego ludzie księcia Henryka ${ }^{105}$. Jan Długosz w Rocznikach zapisał, iż Paweł ,jako gorący przeciwnik księcia Henryka wrocławskiego, ogołocony ze wszystkiego dostał się do niewoli i przez jakiś czas był traktowany jako jeniec" ${ }^{106}$. Represje względem biskupa nie ograniczyły się tylko do pozbawienia go wolności. Z dokumentu wystawionego w lutym 1291 r. przez Henryka z Wstowa, którym przekazuje Wacławowi II zamki w Skale i Sławkowie, wiadomo, że zostały one powierzone jego opiece przez Henryka IV ${ }^{107}$. Sławków był posiadłością biskupią, zatem wynika z tego dyplomu, iż Probus zajął majątki należące do Pawła z Przemankowa. Książę krakowsko-wrocławski nie miał też skrupułów, aby podnieść rękę na ruchomą własność kościelną. W swoim testamencie nakazał bowiem, aby Kościołowi krakowskiemu i tynieckiemu zwrócić zrabowane ornaty, księgi i inne paramenty liturgiczne ${ }^{108}$.

Nie sposób ustalić, jak długo był więziony Paweł z Przemankowa. Jedyną wskazówkę podaje Jan Długosz, według którego biskup ,przez jakiś czas był traktowany jako jeniec" i odzyskał wolność razem z innymi wziętymi do niewoli zwolennikami Łokietka ${ }^{109}$. Oznaczałoby to, że i on ugiął się pod wpływem repre-

${ }^{102}$ T. Nowakowski, op. cit., s. 16.

${ }^{103}$ A. Semkowicz, Walka o monarchia..., s. 737; W. Karasiewicz, Pawet z Przemankowa ..., s. 228. Odmienne stanowisko zajął natomiast T. Nowakowski, op. cit., s. 20.

${ }^{104}$ Rocznik Traski, s. 852: Episcopus Paulus captivatur; Rocznik Sędziwoja, s. 879: Eodem anno Paulus episcopus captivatur; Rocznik małopolski Szamotulskiego, s. 185: Episcopus Paulus captivatur.

${ }^{105}$ Rocznik krakowski, s. 852: [...] episcopus Paulus per homines ducis Henrici et Cracovia capta est.

${ }^{106}$ J. Długosz, op. cit., ks. 7-8, s. 329.

${ }^{107}$ Regesta diplomatica nec non epistolaria Bohemiae et Moraviae, t. 2, wyd. J. Emler, Praga 1882, $\mathrm{nr} 1531$.

${ }^{108} \mathrm{KDW}, \mathrm{t} .2$, nr 645.

${ }^{109}$ J. Długosz, op. cit., ks. 7-8, s. 329. 
sji, które go dotknęły i uznał władzę Henryka IV. Przejścia ordynariusza krakowskiego na stronę księcia śląskiego domyślał się T. Nowakowski ${ }^{110}$. Jednak część historyków, reprezentowana przez A. Semkowicza, E. Długopolskiego, J. Tęgowskiego, a ostatnio również A. Swieżawskiego, przyjmowała, że Paweł przebywał w więzieniu aż do śmierci Probusa i został uwolniony dopiero przez Przemysła II, kiedy ten objął rządy w Krakowie ${ }^{111}$. Byłoby to zatem możliwe najwcześniej około lipca 1290 r., więc biskup spędziłby w więzieniu blisko rok ${ }^{112}$. Niezależnie od tego, kiedy i przez którego z władców krakowskich został uwolniony ordynariusz krakowski, raczej nie zawarł on żadnej ugody z Henrykiem IV. Książę ten dopiero w swoim testamencie postanowił wynagrodzić krzywdy wyrządzone Kościołowi krakowskiemu i polecił zwrócić zrabowane mu sprzęty kościelne, a Przemysła II zobowiązał, aby wypłacił katedrze krakowskiej 100 grzywien złota z przeznaczeniem na założenie nowego klasztoru ${ }^{113}$.

Nic więcej źródła narracyjne nie wspominają o działalności politycznej Pawła z Przemankowa. Choć zachowały się dokumenty dotyczące kontaktów biskupa z Przemysłem II oraz Wacławem II, na próżno szukać takich informacji wśród zapisek rocznikarskich czy w relacjach kronikarzy. Najbardziej zaskakujący jest brak jakichkolwiek odniesień do rozmów prowadzonych przez biskupa z królem czeskim, w których Paweł odegrał bardzo ważną rolę, będąc głównym adresatem przywilejów wystawionych przez monarchę w Lutomyślu ${ }^{114}$. Wydaje się, że udział ordynariusza krakowskiego $\mathrm{w}$ tych wydarzeniach szybko popadł $\mathrm{w}$ niepamięć lub fakt ten po prostu nie wydawał się ówczesnym ludziom istotny.

Najstarsze informacje o działalności politycznej Pawła z Przemankowa pojawiają się w źródłach narracyjnych dopiero w połowie XIV w. Odnoszą się one do udziału Pawła z Przemankowa w buncie przeciwko panowaniu Bolesława Wstydliwego, jego kontaktów z Litwinami czy też dwukrotnego uwięzienia. Wydaje się, że biskup rzeczywiście miał jakieś powiązania z rebeliantami, choć nie sposób orzec, jaką rolę odegrał w tych wydarzeniach. Uczestnictwo w tym spisku mogło mieć znaczący wpływ na to, jak Paweł z Przemankowa został uwiecz-

${ }^{110}$ T. Nowakowski, op. cit., s. 25.

${ }^{111}$ A. Semkowicz, Walka o monarchia..., s. 752; E. Długopolski, Władysław Łokietek na tle swoich czasów, Wrocław 1951, s. 7; J. Tęgowski, op. cit., s. 55; A. Swieżawski, Przemyst - król Polski, Warszawa 2006, s. 134.

112 Pierwszy dokument wystawiony przez Przemysła II w Krakowie, który nie budzi żadnych wątpliwości co do jego autentyczności, datowany jest na 25 lipca 1290 r. (KDM, t. 2, nr 515). A. Swieżawski (op. cit., s. 133) przypuszczał, że Przemysł II przybył do Krakowa już na początku tego miesiąca lub nawet w ostatnich dniach czerwca.

${ }^{113}$ KDW, t. 2, nr 645: Volumus insuper et iubemus, ut dux Polonie, noster heres per terras Cracovie, ad ecclesiam sancti Wenzeslai in Cracovia pro novo monasterio construendo distribuat centum marcas auri. Preterea ornatum, libros et res quascumque Cracoviensis et Tinciensis ecclesie restitui volumus per quoslibet detentores.

${ }^{114}$ KDKK, t. 1, nr 94-95. 
niony na kartach kronik. Niewykluczone, że już wówczas skonfliktowany z biskupem dwór książęcy zaczął rozpowszechniać oskarżenia ordynariusza krakowskiego o sprowadzenie najazdu litewskiego, do którego powróciło w latach późniejszych otoczenie Leszka Czarnego. Tworzący w drugiej połowie XV w. Jan Długosz, dysponując oprócz tych opinii także informacjami o uwięzieniu Pawła, mógł widzieć w nim przede wszystkim polityka chcącego decydować o obsadzie tronu krakowskiego. Przypisał mu zatem przywódczą rolę podczas elekcji nowego władcy po śmierci Leszka Czarnego oraz uczestnictwo w każdym buncie, jaki wybuchł w księstwie krakowsko-sandomierskim za jego pontyfikatu.

\section{ZARZUTY DOTYCZĄCE POSTAWY MORALNEJ BISKUPA PAWŁA Z PRZEMANKOWA}

Drugi element, składający się na czarną legendę Pawła z Przemankowa, stanowią pojawiające się w źródłach narracyjnych liczne zastrzeżenia co do zgodności z zasadami moralnymi prowadzonego przez Pawła z Przemankowa życia. Największym chyba zarzutem, który stawiają biskupowi autorzy IV i V redakcji $\mathrm{Ka}$ talogu biskupów krakowskich, jest to, że prowadził on życie rozwiązłe. Pewnego razu miał siłą wywieźć mniszkę z klasztoru skalskiego i przetrzymywać na swoim dworze w towarzystwie innych panien ${ }^{115}$. Jan Długosz, który nie omieszkał umieścić tego oskarżenia w swoich Rocznikach, dodał, że ordynariusz krakowski ,oddany najpierw rozpuście i rozkoszom zmysłowym, porwał gwałtem pewną mniszkę za Skały P. Marii i żył z nią jak z nałożnicą""16. Źródła te zarzucają Pawłowi z Przemankowa złamanie zasady celibatu, która obowiązywała go jako osobę duchowną. $Z$ relacji tych wynika również, że porwana mniszka nie była jedyną kobietą, z którą współżył. Na dworze biskupim przetrzymywane miały być też inne panny, co sugeruje wręcz, że Paweł miał własny harem.

Zarzut rozwiązłego życia prowadzonego przez biskupa krakowskiego wydaje się mało prawdopodobny. Jak zauważył A. Semkowicz, za życie w konkubinacie musiałyby spaść na niego odpowiednie kary kościelne, a o takowych nic nie wiadomo ${ }^{117}$. Brak informacji o sankcjach jednak całkowicie nie wyklucza możliwości

${ }^{115}$ Katalogi biskupów krakowskich. Redakcja IV świętokrzyska, s. 64: Hic fuit vite dissolute et quandam monialem de Scala recepit violenter ad eam in curia sua publice cum comitatu aliarum virginum retinuit; Redakcja V dominikańska, MPH, s.n., t. 10, cz. 2, s. 99: Hic fuit vite dissolute et quandam monialem de Scala receperat violenter ad eam in curia sua publice cum comitatu aliarum virginum ducebat.

${ }^{116}$ J. Długosz, op. cit., ks. 7-8, s. 222.

117 A. Semkowicz, Rec. B. Ulanowski, Przyczynek do dziejów Pawła z Przemankowa..., 1885, s. 250. Zgodnie ze statutami synodu łęczyckiego duchowni żyjący w konkubinacie podlegali karze ekskomuniki ipso facto. Zob. Starodawne prawa polskiego pomniki poprzedzone wywodem historyczno krytycznym tak zwanego Prawodawstwa Wiślickiego Kazimiérza Wielkiego w texcie ze starych rękopism krytycznie dobranym, wyd. A.Z. Helcel, Warszawa 1856, s. 384-358. 
złamania celibatu przez Pawła z Przemankowa. Tylko pół wieku wcześniej zmarł biskup włocławski Ogierz, który jako ostatni z hierarchów polskiego Kościoła miał legalną małżonkę ${ }^{118}$. Duchowieństwo długo nie chciało się pogodzić z obowiązkiem bezżeństwa wprowadzonym przez reformy Henryka Kietlicza. Wydaje się, że problem życia kapłanów w konkubinacie był aktualny także w czasach Pawła z Przemankowa, skoro kwestię tę poruszały statuty synodów: wrocławskiego z 1267 r. oraz łęczyckiego z 1285 r. ${ }^{119}$ Może więc i sam biskup krakowski miał na sumieniu rozwiązłe życie, choć informacja o utrzymywaniu przez niego całego haremu niewątpliwie została wyolbrzymiona.

Kwestia porwania przez Pawła mniszki ze skalskiego klasztoru jest raczej zwykłym oszczerstwem. Przeciwko autentyczności tego wydarzenia zdają się świadczyć bliskie stosunki, jakie biskup krakowski utrzymywał z klaryskami. Jak trafnie zauważył W. Karasiewicz, Paweł z Przemankowa nie mógł być zarówno obrońcą, jak i krzywdzicielem mniszek. Nie zostałby również wybrany przez legata Filipa z Firmo na mediatora w sporze między księżną Kingą a Leszkiem Czarnym, gdyby miał złą opinię wśród zakonnic i duchowieństwa ${ }^{120}$. Być może właśnie owa współpraca biskupa z wdową po Bolesławie Wstydliwym i konwentem sądeckim przyczyniła się do powstania plotek o współżyciu Pawła z jedną z sióstr, rozpowszechnianych przez jego przeciwników.

Jan Długosz w swoim Katalogu biskupów krakowskich zaznaczył, że z powodu porwania owej mniszki ze Skały oraz ,wielu zbrodni” scholastyk i inni kanonicy krakowscy wytoczyli swojemu zwierzchnikowi proces w kurii rzymskiej. Choć tym razem kronikarz podkreślił, że nie wiadomo, czy owe przyczyny prowadzonego w Stolicy Apostolskiej sporu są prawdziwe czy fałszywe, to sam fakt konfliktu między kapitułą a biskupem krakowskim uznawał za pewny ${ }^{121}$. Aby go jeszcze dobitniej ukazać, Długosz przytoczył inny incydent na niego wskazujący. Otóż pewnego razu, gdy Paweł z Przemankowa gościł na łowach w swoich dobrach kieleckich, przybyli do niego prałaci i kanonicy krakowscy, aby upomnieć go z powodu gorszącego życia, które prowadził. Paweł zaprosił ich na ucztę, a duchowni, nie przeczuwając żadnego podstępu, chętnie na to przystali. Tymczasem pod stołami biskup kazał umieścić karłów, którzy w trakcie posiłku kłuli szpilkami czcigodnych kanoników. Paweł uznał podskakujących co raz współbiesiadników za szalonych i jako takich kazał powiązać oraz wrzucić do więzienia ${ }^{122}$.

${ }^{118}$ J. Maciejewski, op. cit., s. 30.

${ }^{119}$ Zob. T. Gromnicki, Synody prowincjonalne oraz czynności niektórych funkcyonaryuszów apostolskich w Polsce do r. 1357, Kraków 1885, s. 116, 196-197.

${ }^{120}$ W. Karasiewicz, Pawet z Przemankowa ..., s. 234.

${ }^{121}$ Katalog Dlugosza, s. 179: Hic Paulus cum scholastico et certis canonicis ecclesise sue in Romana curia longo tempore litigauit, defferentibus cum predictis scholastico et canonicis apud sedem appostolicam false ne, incertum habetur, an vero de multis criminibus et signanter quod guandam sanctimonialem de monasterio Skala abstractam pro concubina tenebat.

${ }^{122}$ Ibidem, s. 181-182. 
Opowiadanie to wydaje się być raczej fantastyczne i jest mało prawdopodobne, aby miało w ogóle związek z życiem Pawła z Przemankowa. W Karasiewicz sugerował, iż Długosz, znalazłszy tę historię, nie wiedział za bardzo kogo ona dotyczyła i gdzie należało ją umieścić. Uznał więc, że świetnie pasuje do życiorysu tak czarnej postaci, jaką nakreślił, pisząc o biskupie Pawle ${ }^{123}$.

Również sam konflikt, który miał mieć miejsce między ordynariuszem krakowskim a podległą mu kapitułą, budzi spore wątpliwości. Przede wszystkim nic nie wiadomo o jakimkolwiek procesie prowadzonym w tej sprawie w kurii rzymskiej. Jedyna poświadczona sprawa dotycząca Pawła z Przemankowa, z którą kanonicy podróżowali do Stolicy Apostolskiej, dotyczyła jego uwięzienia w Sieradzu przez Leszka Czarnego. Z relacji wysłanników kapituły, jaką przedstawili oni papieżowi Marcinowi IV, nie przebrzmiewa jakakolwiek skarga na życie prowadzone przez ordynariusza krakowskiego. Wręcz przeciwnie, został on ukazany jako sam Chrystus, wydany pocałunkiem przez Judasza, w którego rolę wcielił się książę krakowsko-sandomiersko-sieradzki ${ }^{124}$. Zresztą sam fakt podróży kanoników do Rzymu w celu uzyskania pomocy papieża dla ich uwięzionego pasterza zdaje się świadczyć, że przynajmniej część kapituły była mu przychylna.

Raczej na współpracę, a nie na konflikt między biskupem i kanonikami krakowskimi, wskazują też wystawione przez niego dokumenty. 15 maja 1273 r. Paweł z Przemankowa odstąpił kapitule swój dział, który posiadał we wsi Skrzyszowice i przyłączył ją do wsi kapitulnej Łosośkowice, w zamian za co otrzymał 15 grzywien srebra ${ }^{125}$. Następnie jeszcze tego samego dnia kapituła za zgodą ordynariusza zrzekła się owej wsi na rzecz kanonika płockiego i krakowskiego Filipa. W zamian za dożywotnie posiadanie Łosośkowic zobowiązał się on płacić każdego roku na święto Oczyszczenia Najświętszej Maryi Panny czynsz w wysokości półtorej grzywny srebra pospolitego ${ }^{126}$. Nie był to jednak koniec nabytków kanonika Filipa. 30 września 1273 r. Paweł z Przemankowa zatwierdził zamianę gruntów między Filipem a rycerzem Wojenem, który był właścicielem części gruntów w Łosośkowicach. W zamian za ten majątek kanonik odstąpił mu nabyty uprzednio od biskupa dział w Skrzeszowicach ${ }^{127}$. Tym sposobem w rękach Filipa znalazła się cała wieś Łosośkowice. Kolejna transakcja z jego udziałem miała miejsce 30 września 1279 r., kiedy zamienił swój dział we wsi Trątnowice na część wsi Goszcza, należącej do Imrama, syna Komesa Krystyna z Niedźwiedzia. Za finalizację tego układu odpowiedzialny był scholastyk krakowski Prokop, działający z upoważnienia Pawła z Przemankowa oraz kapituły, a zatwierdził go Bolesław

\footnotetext{
${ }^{123}$ W. Karasiewicz, Pawet z Przemankowa ..., s. 239.

${ }^{124}$ KDKK, t. 1, nr 84.

${ }^{125}$ Ibidem, $\mathrm{nr} 70$.

${ }^{126}$ Ibidem, $\mathrm{nr} 71$.

${ }^{127}$ Ibidem, $\mathrm{nr} 75$.
} 
Wstydliwy ${ }^{128}$. Za zgodą i z upoważnienia biskupa działali też dziekan Gerard i kapituła krakowska, kiedy 22 lutego 1277 r. przekazali księżnej Kindze należący do nich plac w Krakowie. Nadanie to biskup Paweł zatwierdził swoją pieczęcią ${ }^{129}$.

Wszystkie te transakcje raczej nie byłyby możliwe, gdyby kanonicy byli skłóceni z ordynariuszem krakowskim. Zdają się one przemawiać za współpracą między biskupem i kapitułą. O tym samym świadczyć może także testament scholastyka Wysza, który przekazał nim dwie wsie: Świniarsko i Muszynę, na rzecz stołu biskupiego krakowskiego. Zapisanie owych majątków Pawłowi z Przemankowa przez posiadającego krewnych prałata wskazuje na przyjazne stosunki między nimi ${ }^{130}$.

Kapituła krakowska była także odbiorcą ostatniego znanego dokumentu wystawionego przez Pawła z Przemankowa 6 maja 1292 r. w Krakowie. Biskup zatwierdzał w nim kanonikom annum gratiae, nadany przez jego poprzedników, a mający na celu zapewnienie koniecznych funduszy na spłacenie długów po ich śmierci oraz ufundowanie nabożeństw żałobnych. Przywilej ten nie dotyczył jednakże prałatów i kanoników nierezydujących przy katedrze bez słusznej przyczyny ${ }^{131}$.

Wiadomo również, że swoją ostatnią wolą Paweł z Przemankowa przekazał kapitule krakowskiej wieś Dobranowice ${ }^{132}$. Wszystkie omówione powyżej decyzje zdają się wskazywać na dobre stosunki między kanonikami a biskupem w różnych etapach jego pasterskiej posługi w Krakowie. Można zatem przypuszczać, że w ciągu 26 lat urzędowania tego ordynariusza krakowskiego jego relacje z kapitułą układały się raczej pomyślnie. Niestety, niewielka ilość zachowanych dyplomów dotyczących tego zagadnienia nie pozwala z całą pewnością stwierdzić, czy nie zdarzyły się jakieś mniejsze zatargi Pawła z kanonikami. Konfliktów na większą skalę prawdopodobnie nie było, w przeciwnym razie zachowałyby się jakieś informacje na ten temat w źródłach bliższych chronologicznie życiu Pawła z Przemankowa niż Katalog biskupów krakowskich Jana Długosza.

${ }^{128}$ Ibidem, nr 81.

${ }^{129}$ Codex diplomaticus Poloniae, t. 3, nr 52.

${ }^{130} \mathrm{KDKK}$, t. 1, nr 89-90.

${ }^{131} \mathrm{KDKK}, \mathrm{t} .1$, nr 96. Wydaje się, że ordynariusz krakowski, wystawiając ten dyplom, przygotowywał się już do swojej śmierci, bowiem zarządził ut pia memoria Animarum tam Precedessorum quam nostre, quam nostrorum eciam successorum melior semper in Officiis Vigiliarum et missarum pro defunctis in Cracoviensi Ecclesie diligencius habeatur.

132 Niestety, testament Pawła z Przemankowa się nie zachował. Sprawa nadania kapitule Dobranowic znana jest z dokumentu Jana Muskaty z 1295 r. (KDKK, t. 1, nr 99). Wynika z niego, że wbrew ostatniej woli zmarłego biskupa jego bratanek Paweł zajął ową wieś siłą, co ściągnęło na niego klątwę, a kościół w Przemankowie został obłożony interdyktem. Ugodę z Muskatą w imieniu swojego nepotis zawarł Prandota, syn Warsza, kasztelana krakowskiego, posługujący się herbem Rawa. 
Porwanie mniszki ze Skały, które miało poróżnić biskupa krakowskiego z kapitułą, nie było jedynym występkiem, które mu przypisywano. Otóż Katalogi biskupów krakowskich zarzucają mu, że niegodnie nadał prepozyturę skalbimierską w zamian za 100 grzywien czystego srebra ${ }^{133}$. Jan Długosz z tego jednego faktu uczynił przykład całej działalności symoniackiej prowadzonej przez Pawła z Przemankowa ${ }^{134}$.

O ile Katalogi biskupów krakowskich więcej zarzutów Pawłowi już nie stawiają, o tyle Długosz nie omieszkał przypisać mu również innych przywar, które uzupełniły wizję czarnego charakteru biskupa. Miał on być „gwałtowny i nieznośny dla poddanych i sąsiadów, wobec swojego władcy księcia krakowskiego i sandomierskiego Bolesława Wstydliwego oraz sądów był hardy i niesforny" 135 . Dziejopis zarzucał Pawłowi z Przemankowa, że „bardzo rzadko zajmował się swoją katedrą krakowską, spotykając się nieraz z rycerzami, którzy przywykli żyć z grabieży i rabunku, skazanymi przez sądy i obciążonymi długami" 136 . W Katalogu biskupów krakowskich zapisał natomiast, że Paweł był człowiekiem dbającym raczej o dobra ziemskie i rzadko odczuwał wyrzuty sumienia z powodu popełnionych występków ${ }^{137}$. Jak zauważył A. Semkowicz, za wzór do wykreowania takiego wizerunku biskupa posłużył Długoszowi Zbigniew, syn Władysława Hermana. Mianowicie ,jeden i drugi tajemne ma schadzki z ludźmi trudniącymi się zdzierstwem i kradzieżą, $\mathrm{z}$ winowajcami potępionymi w sądach za zbrodnie i długi"'138.

Kolejną przywarą Pawła z Przemankowa, którą mu przypisywał Jan Długosz, było jego zamiłowanie łowieckie. W swoich Rocznikach wyrzucał mu, że „pozwalał sobie na swawolne życie i nie zważając na godność biskupią, sam osobiście brał udział w polowaniach" ${ }^{139}$. W innym miejscu dodał: „Zajęty ciągle polowaniami po lasach, rzadki gość w kościele i urzędzie, wzywał na siebie pomsty Boga i ludzi"140. Owa pasja łowiecka ponoć była tak wielka, że nawet życie ludzkie miało dla biskupa mniejszą wartość od tej rozrywki. Przekonać się miał o tym pewien myśliwy, który na jednym z polowań w lasach kieleckich przez swo-

${ }^{133}$ Katalogi biskupów krakowskich, s. 64, 99 (tak samo w IV i V redakcji): Hic preposituram Scarbimiriensem collacionis episcopalis, receptis centum marcis puri argendi, cuidam indigno contulerat.

134 Katalog Dtugosza, s. 179: [...] beneficia ecclesiastica, et signanter Praeposituram Scarbimiriensem pretio devicius conferret.

${ }^{135}$ J. Długosz, op. cit., ks. 7-8, s. 222.

${ }^{136}$ Ibidem, s. 230.

137 Katalog Dtugosza, s. 181: Vir crudus, terrenus et mundatus, et qui super facinoribus gravibus raro conscientiae remorsu tangebatur.

${ }^{138}$ A. Semkowicz, Rec. B. Ulanowski, Przyczynek do dziejów Pawła z Przemankowa..., 1885, s. 249.

${ }^{139}$ J. Długosz, op. cit., ks. 7-8, s. 230.

${ }^{140}$ Ibidem, s. 222-223. 
ją nieuwagę spłoszył zwierzynę. Skutki tego były opłakane. Paweł „przebił [go] w gniewie dzidą, którą miał w ręce, nie bojąc się zabić zamiast zwierzęcia człowieka, którego Jednorodzony odkupił swoją krwią"141.

Żadne źródło poza Długoszem nie wspomina ani o zamiłowaniu biskupa do łowów, ani o zabiciu przezeń myśliwego. Tego pierwszego nie można wykluczyć, jako że od 1258 r. biskupi krakowscy posiadali szerokie uprawnienia łowieckie w swoich kasztelaniach, mógł zatem z nich korzystać i Paweł z Przemankowa. Autor Roczników na kartach swojego dzieła nie krył niechęci do polowań i myśliwych. Wyczuwalne jest uprzedzenie Jana Długosza do tych książąt i królów polskich, którzy oddawali się pasji łowieckiej ${ }^{142}$. Nic zatem dziwnego, że wypomniał on udział w tej rozrywce także biskupowi krakowskiemu, któremu jako osobie duchownej nie godziło się mieć tak przyziemnych upodobań.

Zabójstwo człowieka przez Pawła jest niemniej rzeczą niepewną. W. Karasiewicz przypuszczał, że mogła się zdarzyć jakaś historia o morderstwie na polowaniu, dotycząca bliżej nieznanego biskupa. Brak potwierdzenia jej przez wcześniejsze źródła powoduje, że jej związek z życiem Pawła jest wielce wątpliwy ${ }^{143}$. Nie można wykluczyć, że podczas łowów Pawła z Przemankowa zdarzył się jakiś niefortunny wypadek, który doprowadził do śmierci jednego z myśliwych. Informacje o takim zajściu mogły zostać wykorzystane przez przeciwników biskupa do rozpowszechniania pogłosek o rzekomym umyślnym morderstwie.

Należy zauważyć, że wszystkie legendy i anegdoty dotyczące Pawła z Przemankowa pochodzą ze źródeł czternasto- i piętnastowiecznych, które opisywały wydarzenia z życia biskupa z dość odległej perspektywy. Współczesny biskupowi Rocznik kapituły krakowskiej złego zdania o nim nie zapisał. Wręcz przeciwnie, można się z niego dowiedzieć, że na synodzie wrocławskim w 1267 r. legat papieski Gwido ze wszystkich polskich biskupów cenił sobie najbardziej właśnie Pawła, wówczas jeszcze biskupa-elekta krakowskiego ${ }^{144}$. Szczególne względy, ja-

${ }^{141}$ Ibidem, s. 347; Katalog Dhugosza, s. 181: Hic in tantam venationis feruore ferebatur erupisse insaniam vt conditionis pontificalis oblitus, tractando in Kielcensi districtu venationes venatorem, qui feram incautus, ne vsque ad casses delebaretur dispulerat, lancea manu gestata indignabundus perfodere, non veritus hominem pro bestia perdere quem vnigenitus redemit sanguine suo.

${ }^{142}$ Szczególnie widoczna jest niechęć Jana Długosza do znanego z zamiłowań łowieckich Władysława Jagiełły. Wychodził on bowiem z założenia, iż upodobanie w polowaniach, na równi $\mathrm{z}$ nadużywaniem alkoholu, pozbawia moralnego prawa do sprawowania władzy. Zob. R. Jaworski, Łowy Władystawa Jagietty, „Fasciculi Historici Novi” 2001, t. 4, s. 13-16.

${ }^{143}$ W. Karasiewicz, Pawet z Przemankowa ..., s. 239.

${ }^{144}$ Rocznik kapituly krakowskiej, s. 95: Hic [Guido - J.G.] venerabilem patrem dominum Paulum ecclesie Cracouiensis predictum episcopum tunc electum super archiepiscopum et omnes episcopos Polonie fuit propensiori favore et gracia prosequ[u] tus et honoris ampliori preminencia honoravit. Na przyjazne stosunki pomiędzy legatem papieskim a Pawłem z Przemankowa zdaje się też wskazywać jego wizyta w Krakowie na przełomie czerwca i lipca 1267 r. Kardynał Gwidon wystawił tam dokument dla kapituły krakowskiej, nadający odpust odwiedzającym w wyznaczone dni katedrę krakowską. KDKK, t. 1, nr 66. 
kimi obdarzył go pochodzący ze znanego z surowości obyczajów zakonu cysterskiego kardynał, mogłyby świadczyć jeśli nawet nie o wybitnych cnotach Pawła z Przemankowa, to przynajmniej o tym, że prowadził on życie zgodne z normami moralnymi ${ }^{145}$. Nie można jednak wykluczyć, iż przychylność legata była jedynie konsekwencją umiejętnego zaprezentowania się biskupa-elekta podczas obrad synodu. W ten sposób rozumował A. Przeździecki, według którego kardynał Gwidon ,poznał w nim [Pawle z Przemankowa - J.G.] zapewne nieugiętość ducha, wielkich czynów źródło; a nałogi złe, co go miały wkrótce na drogę zbrodni sprowadzić, nie tak straszliwie rozwinięte jeszcze, umiał biskup ukrywać"146.

O ile mógł biskup Paweł zataić swoje wady przed legatem papieskim, który w jego towarzystwie spędził tylko krótki czas, o tyle raczej jest mało prawdopodobne, żeby umknęly one uwadze duchowieństwa polskiego utrzymującego z nim kontakty przez 26 lat urzędowania na katedrze krakowskiej. Tymczasem zgodnie z relacją Rocznika kapitulnego krakowskiego po konsekracji Pawła z Przemankowa nastała wielka radość wśród ludzi zarówno duchownych, jak i świeckich ${ }^{147}$. Raczej nie byłoby owej radości wśród kleru, gdyby na biskupa został wyświęcony niegodny tego urzędu człowiek.

Wydaje się zresztą, że kler rzeczywiście mógł być zadowolony z wyboru ordynariusza krakowskiego i to nie tylko z powodu uroczystości towarzyszących sakrze biskupiej. Jak już wyżej starano się wykazać, relacje Pawła z Przemankowa z podległą mu kapitułą układały się raczej pomyślnie i pozwalały na owocną współpracę z kanonikami. Dobre stosunki łączyły biskupa także z polskim episkopatem, o czym może świadczyć zaangażowanie Pawła w toczący się na Śląsku konflikt między biskupem wrocławskim Tomaszem II a tamtejszym księciem Henrykiem IV Probusem ${ }^{148}$. Do głównych sprzymierzeńców ordynariusza wrocławskiego w owym sporze należy zaliczyć, obok arcybiskupa Jakuba Świnki, właśnie Pawła z Przemankowa. To ich rady zasięgał Tomasz w sprawie warunków ugody z Henrykiem IV ${ }^{149}$. Jednym z warunków podjęcia rozmów między zwaśnionymi stronami, które miały odbyć się w Opolu 1 kwietnia 1287 r., był udział w nich Jakuba Świnki oraz Pawła z Przemankowa ${ }^{150}$. Co ciekawe, obecność ordy-

${ }^{145}$ Zob. W. Karasiewicz, Pawet z Przemankowa..., s. 163, 233-234; J. Wyrozumski, op. cit., s. 391.

${ }^{146}$ A. Przeździecki, op. cit., s. 6.

${ }^{147}$ Rocznik kapituly krakowskiej, s. 94: Et tunc facta est leticia magna in populo tam clero quam laycis, ita eciam, quod leti festas duxere coreas.

${ }^{148} \mathrm{O}$ konflikcie pomiędzy biskupem Tomaszem II i Henrykiem IV zob. T. Gromnicki, op. cit., s. 139-142, 186-190, 207-215; W. Karasiewicz, Jakób II Świnka, arcybiskup gnieźnieński 12831314, „Poznańskie Towarzystwo Przyjaciół Nauk. Prace Komisji Teologicznej” 1938, t. 3, z. 3, s. 248-275; P. Żmudzki, op. cit., s. 331-333, 384-387, 449-452.

${ }^{149}$ Urkunden zur Geschichte des Bisthums Breslau im Mittelalter, wyd. G.A. Stenzel, Breslau 1845, nr 198.

${ }^{150}$ Ibidem, nr 224. 
nariusza krakowskiego na negocjacjach za konieczną i pożyteczną dla osiągnięcia zgody uznał też książę opolski Bolesław, który był jednym z pełnomocników Henryka IV ${ }^{151}$. Świadczyłoby to o tym, że Paweł cieszył się poważaniem nie tylko ze strony duchowieństwa, ale i elit świeckich. Wreszcie biskup krakowski udzielił schronienia Tomaszowi II, kiedy ten wobec gróźb Probusa musiał uchodzić ze Śląska, o czym informuje list arcybiskupa Jakuba Świnki adresowany do obu tych hierarchów ${ }^{152}$.

Przebieg sporu między biskupem Tomaszem i Henrykiem Probusem zdaje się świadczyć o bliskiej współpracy Pawła z Przemankowa zarówno z ordynariuszem wrocławskim, jak i arcybiskupem Jakubem Świnką. Fakt, że Tomasz II korzystał z porad biskupa krakowskiego, a później nalegał na jego obecność podczas negocjacji opolskich, wskazuje na pewien autorytet, jakim Paweł cieszył się wśród hierarchów metropolii gnieźnieńskiej.

W dobrym świetle przedstawia ordynariusza krakowskiego również powstały około 30 lat od jego śmierci Żywot świętej Kingi. Zdaniem B. Kowalskiej, gdyby Paweł był w jakiś sposób skonfliktowany z klaryskami, hagiograf księżnej nie omieszkałby tego odnotować, co stało się udziałem Leszka Czarnego. Można przypuszczać, że i owo porwanie mniszki z konwentu skalskiego, gdyby rzeczywiście miało miejsce, znalazłoby swoje odzwierciedlenie w żywocie. Wydaje się jednak, że jego autor dobrze znał atmosferę panującą w klasztorze sądeckim na początku XIV w. Na kartach Żywota świętej Kingi został uwieczniony wizerunek Pawła z Przemankowa jako biskupa czcigodnego i dobrego. Właśnie taka tradycja o ordynariuszu krakowskim była pielęgnowana przez klaryski sądeckie, które były głównymi informatorkami hagiografa ${ }^{153}$.

Według A. Semkowicza nie ma także podstaw, aby nie wierzyć, iż podczas elekcji biskupa krakowskiego opowiedziano się za najgodniejszym z kanoników. W końcu elektorzy weszli do kapituły z nominacji świątobliwego biskupa Prandoty, a więc zapewne sami byli pobożnymi kapłanami i niewątpliwie nie wybraliby na swojego pasterza rozpustnego człowieka ${ }^{154}$.

Skąd zatem w źródłach pojawiają się tak liczne informacje o niegodnym postępowaniu Pawła z Przemankowa? Na taką opinię mógł wpłynąć przede wszystkim czas jego urzędowania. W porównaniu do swojego świątobliwego poprzednika, biskupa Prandoty, jego pobożność rzeczywiście mogła wypaść dość słabo. Wydaje się, że reputacji Pawła zaszkodził też jeden z następców, Jan Muskata,

${ }^{151}$ Ibidem, nr 238.

${ }^{152}$ Ibidem, nr 240.

${ }^{153}$ B. Kowalska, Biskup krakowski Paweł z Przemankowa a klasztor klarysek w Starym Saczu, „Prace Naukowe Akademii im. Jana Długosza w Częstochowie. Zeszyty Historyczne” 2009, z. 10, s. 37.

${ }^{154}$ A. Semkowicz, Rec. B. Ulanowski, Przyczynek do dziejów Pawła z Przemankowa..., 1885, s. 247. 
którego wstąpienie na katedrę krakowską rozdzielił tylko krótki pontyfikat biskupa Prokopa. Jak pisał A. Rybarski, ,ponieważ wskutek zatargów z panującymi książętami losy obydwóch dostojników wykazywały pewne podobieństwo, przeto tradycja późniejsza, zwłaszcza Długosz, pomieszała szczegóły odnoszące się do biskupa Pawła z wypadkami Jana Muskaty"155. I rzeczywiście, jeśli prześledzi się akta procesów prowadzonych przeciw biskupowi Janowi, znajdują się w nich zarzuty analogiczne do tych, które źródła narracyjne przypisują Pawłowi z Przemankowa. Tak oto Muskata oskarżony był o cudzołóstwo i zniesławienie Gerussy, córki wójta sądeckiego. Złą sławą cieszyli się jego podwładni, oskarżani o plądrowanie i podpalanie kościołów, liczne zabójstwa oraz gwałty dokonywane na niewiastach zamieszkujących dobra kościelne. Biskupa Jana posądzano również o symonię, w tym przekupienie elektorów podczas jego wyboru ${ }^{156}$. W obronie Muskaty stawał natomiast prepozyt skarbimierski Engelbert, który objął ten urząd prawdopodobnie właśnie z nominacji tego biskupa ${ }^{157}$. Jak spostrzegł W. Karasiewicz, w swoich dziełach Jan Długosz nie stawiał większych zarzutów Janowi Muskacie, choć akta wytoczonych mu procesów świadczą o prowadzeniu przezeń życia niegodnego piastowanego urzędu. Daje więc to podstawę do przypuszczeń, że większość występków przypisywanych Pawłowi z Przemankowa odnosi się w rzeczywistości do dziejów jego następcy na katedrze krakowskiej ${ }^{158}$.

Zdaniem J. Wyrozumskiego biskup naraził się opinii potomnych, a w szczególności kształtującej się wokół zjednoczeniowych dążeń Władysława Łokietka tradycji krakowskiej, przede wszystkim poparciem udzielonym Wacławowi II. $\mathrm{Z}$ tego powodu traktowano go na równi z Janem Muskatą ${ }^{159}$. Nie można wykluczyć, że mogło to spowodować przypisanie Pawłowi z Przemankowa przewinień jego następcy, choć należy pamiętać, że żadne ze źródeł narracyjnych o jego kontaktach z królem czeskim nie wspomina.

P. Żmudzki początki powstawania czarnej legendy biskupa Pawła datował na panowanie Bolesława Wstydliwego. Jego zdaniem już wówczas rozpowszechniane były przez dwór książęcy pogłoski o sprowadzeniu przez ordynariusza krakowskiego najazdu Litwinów na ziemię lubelską w 1273 r. Propagowanie owych obraźliwych pomówień miało być zemstą za koneksje Pawła z Przemankowa ze zbuntowanym rycerstwem ${ }^{160}$. Do nagłaśniania plotek o rzekomych związkach bi-

${ }^{155}$ A. Rybarski, op. cit., s. 1.

${ }^{156}$ Monumenta Poloniae Vaticana, t. 3: Analecta Vaticana 1202-1366, wyd. J. Ptaśnik, Kraków 1914, nr 121.

${ }^{157}$ Ibidem, nr 128, 130. Engelbert pojawia się po raz pierwszy w 1302 r. jako kanonik krakowski, a w latach 1306, 1320 i 1322 występuje na dokumentach również jako prepozyt skarbimierski. Zob. F. Piekosiński, op. cit., s. 251.

${ }^{158}$ W. Karasiewicz, Pawet z Przemankowa ..., s. 234-240.

159 J. Wyrozumski, op. cit., s. 393.

${ }^{160}$ P. Żmudzki, op. cit., s. 237. 
skupa z poganami powrócił dwór Leszka Czarnego w latach konfliktu księcia z biskupem. Wspierający władcę dominikanie mieli wtedy rozpowszechniać również kolejne absurdalne zarzuty stawiane Pawłowi. Owa propaganda była na tyle skuteczna, że czarna legenda zakorzeniła się na długie lata w historiografii. Jan Długosz uczynił go już bowiem ucieleśnieniem wszelkich wad i grzechów złego hierarchy kościelnego, przypisując mu też przewinienia Jana Muskaty ${ }^{161}$.

W. Bielak przypuszczał, że ukazanie Pawła z Przemankowa w skrajnie niekorzystnym dla niego świetle przez tego piętnastowiecznego historyka było konsekwencją stosunku biskupa do władcy. Według Długosza dobry pasterz potrafił zachować dobre relacje z aktualnie panującym monarchą. Paweł, który według kronikarza miał uczestniczyć w trzech buntach przeciw książętom, nie mógł zatem mieć u niego dobrej opinii. Sprzymierzający się z obcymi władcami biskup został zatem przedstawiony w najczarniejszych barwach. Co innego Jan Muskata, który wiernie służył Wacławowi II jako władcy krakowskiemu, a potem królowi Polski. Wprawdzie początkowo Jan Długosz był oburzony sprowadzeniem czeskiego króla do Krakowa, ale z czasem, kiedy jego władza się ugruntowała i obdarował Kościół swoimi nadaniami, niechęć do przedstawiciela dynastii Przemyślidów minęła. Stąd na kartach Roczników wizerunek Muskaty jest o wiele korzystniejszy niż Pawła z Przemankowa ${ }^{162}$.

Wydaje się, że szukanie przyczyn powstania czarnej legendy ordynariusza krakowskiego w mentalności Jana Długosza jest słuszną decyzją, choć niekoniecznie akurat stosunek Pawła do władców zadecydował o przedstawieniu jego osoby w sposób negatywny. Kronikarz prezentował bowiem w swoich dziełach schematyczne wizerunki dobrego władcy czy duchownego, będące odzwierciedleniem wzorca osobowego, oraz ich negatywne odpowiedniki. Opisywana przez niego postać była dopasowywana do jednej z tych kategorii ${ }^{163}$.

M. Koczerska w swoich badaniach nad mentalnością Długosza przedstawiła katalog cech charakteryzujących złego biskupa. Zaliczyła do nich pychę, rozwiązłość, życie światowe, wytworność w ubiorze, pobłażanie występkom, działanie bez zgody kapituły, obojętność na występki władcy oraz nepotyzm ${ }^{164}$. Łatwo zauważyć, że większoość z nich można odnaleźć w Długoszowym wizerunku Pawła z Przemankowa, który - według kronikarza - był człowiekiem wyniosłym, światowym, skłóconym z kapitułą, prowadzącym rozwiązłe życie. Widać zatem, że ordynariusz krakowski został przedstawiony jako antywzorzec biskupa. Dlaczego Jan Długosz przedstawił go akurat w negatywnym świetle? Zdaniem M. Koczerskiej podstawą uznania biskupa przez kronikarza za postać pozytywną było wypełnianie przez niego obowiązków duszpasterskich oraz brak cech negatyw-

${ }^{161}$ Ibidem, s. 325-326.

${ }^{162}$ W. Bielak, op. cit., s. 222, 227-228.

${ }^{163}$ M. Koczerska, op. cit., s. 118.

${ }^{164}$ Ibidem, s. 125. 
nych: naruszania celibatu i nepotyzmu ${ }^{165}$. Jak zauważyła U. Borkowska, według Długosza biskup miał być przede wszystkim duszpasterzem, a nie mężem stanu. Jeśli jednak to polityka była dla niego najważniejszym zajęciem, wówczas dla kronikarza był niegodnym piastowanego urzędu ${ }^{166}$. Jan Długosz, opisując cechy Pawła z Przemankowa, dysponował informacjami o porwaniu przez niego mniszki z klasztoru skalskiego, konflikcie z Bolesławem Wstydliwym czy związkach z buntem w 1273 r. Ordynariusz krakowski, który - jak informowały wcześniejsze źródła - prowadził rozwiązłe życie i uczestniczył aktywnie w życiu politycznym, nie mógł być ideałem biskupa, dlatego został przedstawiony w negatywnym świetle. Wydaje się, że portret Pawła, jaki Długosz przedstawił w swoich dziełach, należy raczej traktować jako wizerunek typiczny, a nie jego rzeczywistą charakterystykę ${ }^{167}$.

Dzięki „przysłudze”, jaką Długosz oddał Pawłowi z Przemankowa, dla kolejnych pokoleń jawił się on już jako antywzorzec biskupa ${ }^{168}$. Wyrazem tego są chociażby poglądy A. Przeździeckiego, który w połowie XIX w. napisał pierwszą biografię tego ordynariusza krakowskiego. Jego zdaniem ,niecnym był jako człowiek i jako kapłan Paweł z Przemankowa. Jako pan krakowski, przedłużał tylko szereg potężnych i dumnych możnowładców, którzy zacząwszy od Sieciecha i Skarbimira, a kończąc na Wincentym z Szamotuł, trzęśli powagą książęcą, i uginali ją pod jarzmo baronów". Według Przeździeckiego jedynym pozytywnym akcentem z życia biskupa było to, że popierał stronnictwo „książąt krajowych” i sprzeciwiał się władcom zniemczałym ${ }^{169}$. W podobnym tonie o Pawle z Przemankowa wypowiadał się L. Łętowski, pisząc o nim, iż to „był człowiek gruby, oddany światowym rzeczom, niemający sumienia żadnego, chociaż nie bez wiary; istny obraz wielu ludzi wieku swego" ${ }^{170}$. W odróżnieniu od A. Przeździeckiego dostrzegł zatem w Pawle jakiś promień wiary niezbędnej do wykonywania posługi przez osobę duchowną. Korzystając w głównej mierze z tradycji przekazanej przez Jana Długosza oraz opierając się na pracach tych dwóch dziewiętnastowiecznych historyków, literacki obraz Pawła z Przemankowa stworzył J.I. Kraszewski. W powieści zatytułowanej Syn Jazdona, zgodnie z ówczesnym stanem badań, przypisał ordynariuszowi krakowskiemu wszelkie możliwe przewinienia, jakie tylko pojawiły się w źródłach, a więc nawet te, o których wiarygodności sami średniowieczni rocznikarze i Jan Długosz nie byli do końca przekonani ${ }^{171}$.

${ }^{165}$ Ibidem, s. 126.

${ }^{166}$ U. Borkowska, Treści ideowe w dziełach Jana Dlugosza, Lublin 1983, s. 84.

${ }^{167}$ Zob. ibidem, s. 95, przypis 10.

${ }^{168}$ P. Żmudzki, op. cit., s. 325-326.

${ }^{169}$ A. Przeździecki, op. cit., s. 53-54.

${ }^{170}$ L. Łętowski, Katalog biskupów, prałatów i kanoników krakowskich, t. 1, Kraków 1852, s. $186-187$.

${ }^{171}$ J.I. Kraszewski, Syn Jazdona. Powieść historyczna z czasów Bolesława Wstydliwego i Leszka Czarnego, t. 1-3, Kraków 1880. 
Dzieło Kraszewskiego niewątpliwie przyczyniło się do rozpowszechnienia czarnej legendy Pawła z Przemankowa wśród czytelników.

Charakterystykę biskupa przedstawioną przez Długosza przyjmował także B. Ulanowski, zaznaczając, że „nie zachowywał się Paweł odpowiednio [do] wysokiej swej godności" ${ }^{172}$. Dopiero A. Semkowicz pod koniec XIX w. jako pierwszy podjął próbę oczyszczenia biskupa krakowskiego z niesłusznie przypisywanych mu zarzutów ${ }^{173}$.

\section{ZAKOŃCZENIE}

Powstanie czarnej legendy Pawła z Przemankowa wydaje się być powiązane z jego działalnością polityczną. Biskup często zajmował opozycyjne stanowisko wobec władzy świeckiej, co mogło przyczynić się do powstania już wówczas rozmaitych pomówień, rozpowszechnianych przez skupionych wokół dworu książęcego przeciwników. Oskarżano go o spiskowanie przeciw władcom krakowsko-sandomierskim, rozlew krwi w wojnach domowych oraz kontakty z Litwinami, których miał namawiać do łupieżczych wypraw. Konsekwencją politycznych wyborów ordynariusza krakowskiego było jego dwukrotne uwięzienie, co skrupulatnie odnotowali rocznikarze. Historycy, tworzący już z większej perspektywy czasowej, mając do dyspozycji informacje o pozbawieniu wolności biskupa przez Leszka Czarnego oraz Henryka IV, mogli domyślać się w jego osobie awanturnika, który z powodu swoich występków został ukarany. Zaczęli zatem przyporządkowywać do jego życiorysu rozmaite anegdoty, których pochodzenia może nawet nie znali, ale doskonale wydawały im się pasować do tak czarnego charakteru, jakim jawił im się Paweł z Przemankowa. Na utrwalenie skrajnie negatywnego wizerunku biskupa krakowskiego mogła wpłynąć też działalność jednego z jego następców, Jana Muskaty. Z racji tego, że obaj dostojnicy mieli zatargi z panującymi, tracili wolność i popierali rządy Wacława II w księstwie krakowsko-sandomierskim, późniejsza tradycja mogła pomieszać szczegóły z ich życiorysów i w ten sposób Pawłowi przypisano przewinienia Muskaty. Duży wpływ na utrwalenie czarnej legendy ordynariusza krakowskiego miała także mentalność Jana Długosza, który przedstawiając go jako antywzorzec biskupa, przypisał mu zestaw negatywnych cech i postaw. Konsekwencją tych wszystkich czynników było wykreowanie wizerunku biskupa Pawła jako niegodnego infuły wichrzyciela politycznego, prowadzącego rozpustne życie, gwałtownego w swoich poczynaniach, a czasem wręcz nieobliczalnego, niewahającego się nawet dokonać zabójstwa.

${ }^{172}$ B. Ulanowski, op. cit., s. 93.

${ }^{173}$ A. Semkowicz, Rec. B. Ulanowski, Przyczynek do dziejów Pawła z Przemankowa, Kraków 1883, „Przegląd Powszechny” 1884, t. 2, s. 125-127; idem, Rec. B. Ulanowski, Przyczynek do dziejów Pawła z Przemankowa..., 1885, s. 247-252; idem, Krytyczny rozbiór... 
Choć zapewne Paweł nie był wzorem biskupa na miarę swojego poprzednika Prandoty, to jego obraz wyłaniający się ze źródeł narracyjnych niewątpliwie jest przesadzony. Wydaje się, iż rzeczywiście brał on aktywny udział w życiu politycznym księstwa krakowsko-sandomierskiego i mógł nawet mieć znaczący wpływ na obsadę tronu po śmierci Leszka Czarnego. Jednak z otwartym buntem przeciw władcy miał powiązania najprawdopodobniej tylko raz, w 1273 r. Nie mógł też Paweł z Przemankowa być aż tak złym i podstępnym człowiekiem, skoro cieszył się poważaniem wśród polskiego episkopatu i kapituły krakowskiej.

\section{BIBLIOGRAFIA}

\section{Źródla}

Chronica Polonorum, [w:] Monumenta Poloniae Historica, t. 3, wyd. A. Bielowski, Lwów 1878.

Codex diplomaticus Poloniae, t. 3, wyd. L. Rzyszczewski, A. Muczkowski, J. Bartoszewicz, Warszawa 1858.

Długosz J., Roczniki, czyli Kroniki sławnego Królestwa Polskiego, ks. 7-8, przeł. J. Mrukówna, wyd. K. Pieradzka, Warszawa 1974.

Katalog Dlugosza, [w:] Monumenta Poloniae Historica, Series Nova, t. 10, cz. 2, wyd. J. Szymański, Warszawa 1974.

Katalogi biskupów krakowskich, [w:] Monumenta Poloniae Historica, Series Nova, t. 10, cz. 2, wyd. J. Szymański, Warszawa 1974.

Kodeks dyplomatyczny katedry krakowskiej św. Wacława, t. 1, wyd. F. Piekosiński, Kraków 1874.

Kodeks dyplomatyczny Małopolski, t. 1, wyd. F. Piekosiński, Kraków 1876.

Kodeks dyplomatyczny Małopolski, t. 2, wyd. F. Piekosiński, Kraków 1886.

Kodeks dyplomatyczny Wielkopolski, t. 1-2, wyd. 1, Zakrzewski, Poznań 1877-1878.

Monografia opactwa cystersów we wsi Mogile, cz. 2: Zbiór dyplomów klasztoru mogilskiego, Kraków 1867.

Monumenta Poloniae Vaticana, t. 3: Analecta Vaticana 1202-1366, wyd. J. Ptaśnik, Kraków 1914. Regesta diplomatica nec non epistolaria Bohemiae et Moraviae, t. 2, wyd. J. Emler, Praga 1882.

Rocznik franciszkański krakowski, [w:] Monumenta Poloniae Historica, t. 3, wyd. A. Bielowski, Lwów 1878.

Rocznik kapituly krakowskiej, [w:] Monumenta Poloniae Historica, Series Nova, t. 5, wyd. Z. Kozłowska-Budkowa, Warszawa 1978.

Rocznik krakowski, [w:] Monumenta Poloniae Historica, t. 2, wyd. A. Bielowski, Lwów 1872.

Rocznik kujawski, [w:] Monumenta Poloniae Historica, t. 3, wyd. A. Bielowski, Lwów 1878.

Rocznik małopolski Gesselena, [w:] Monumenta Poloniae Historica, t. 3, wyd. A. Bielowski, Lwów 1878.

Rocznik małopolski Kuropatnickiego, [w:] Monumenta Poloniae Historica, t. 3, wyd. A. Bielowski, Lwów 1878.

Rocznik matopolski Szamotulskiego, [w:] Monumenta Poloniae Historica, t. 3, wyd. A. Bielowski, Lwów 1878.

Rocznik miechowski, „Studia Źródłoznawcze”, t. 5, wyd. Z. Budkowa, 1960, s. 119-135.

Rocznik Sędziwoja, [w:] Monumenta Poloniae Historica, t. 2, wyd. A. Bielowski, Lwów 1872.

Rocznik świętokrzyski, [w:] Monumenta Poloniae Historica, t. 3, wyd. A. Bielowski, Lwów 1878.

Rocznik Traski, [w:] Monumenta Poloniae Historica, t. 2, wyd. A. Bielowski, Lwów 1872. 
Starodawne prawa polskiego pomniki poprzedzone wywodem historyczno krytycznym tak zwanego Prawodawstwa Wiślickiego Kazimiérza Wielkiego w texcie ze starych rękopism krytycznie dobranym, wyd. A.Z. Helcel, Warszawa 1856.

Urkunden zur Geschichte des Bisthums Breslau im Mittelalter, wyd. G.A. Stenzel, Breslau 1845.

\section{Literatura}

Białuński G., Studia z dziejów plemion pruskich i jaćwieskich, Olsztyn 1999.

Bielak W., Biskup i jego urzad w oczach średniowiecznych kronikarzy polskich, Lublin 2011.

Błaszczyk G., Dzieje stosunków polsko-litewskich od czasów najdawniejszych do współczesności, t. 1: Trudne początki, Poznań 1998.

Borkowska U., Treści ideowe w dziełach Jana Dlugosza, Lublin 1983.

Długopolski E., Władysław Łokietek na tle swoich czasów, Wrocław 1951.

Gawlas S., O ksztalt zjednoczonego Królestwa, Warszawa 1996.

Gładyszewicz M., Żywot błogosławionego Prandoty z Białczowa biskupa krakowskiego, Kraków 1845

Grodecki R., Dzieje polityczne Śląska do r. 1290, [w:] Historia Śląska od najdawniejszych czasów do roku 1400, red. S. Kutrzeba, t. 1, Kraków 1933, s. 155-326.

Gromnicki T., Synody prowincjonalne oraz czynności niektórych funkcyonaryuszów apostolskich $w$ Polsce do r. 1357, Kraków 1885.

Halecki O., Powołanie księcia Wtadysława opolskiego na tron krakowski w r. 1273, „Kwartalnik Historyczny" 1913, R. 27, s. 213-315.

Jaworski R., Łowy Władystawa Jagiełty, „Fasciculi Historici Novi” 2001, t. 4, s. 7-86.

Karasiewicz W., Jakób II Świnka, arcybiskup gnieźnieński 1283-1314, „Poznańskie Towarzystwo Przyjaciół Nauk. Prace Komisji Teologicznej” 1938, t. 3, z. 3.

Karasiewicz W., Pawet z Przemankowa biskup krakowski 1266-1292, „Nasza Przeszłość” 1959, t. 9, s. $157-247$.

Klimecka G., Ród potomków Sieciecha w wiekach XII-XIII, „Studia Źródłoznawcze” 1983, nr 28, s. 51-67.

Koczerska M., Mentalność Jana Dlugosza w świetle jego twórczości, „Studia Źródłoznawcze” 1970, nr 15, s. 110-140.

Kowalska B., Biskup krakowski Pawet z Przemankowa a klasztor klarysek w Starym Saczu, „Prace Naukowe Akademii im. Jana Długosza w Częstochowie. Zeszyty Historyczne” 2009, z. 10, s. $29-42$.

Krakowski S., Obrona pogranicza wschodniego Małopolski za Leszka Czarnego, „Zeszyty Naukowe Uniwersytetu Łódzkiego. Nauki Humanistyczno-Społeczne" 1960, z. 15, s. 97-114.

Kraszewski J.I., Syn Jazdona. Powieść historyczna z czasów Bolesława Wstydliwego i Leszka Czarnego, t. 1-3, Kraków 1880.

Kurtyka J., Elita małopolska XIII i XIV w. - przerwa czy kontynuacja (na przykladzie Toporów: potomstwo Żegoty wojewody i kasztelana krakowskiego), [w:] Genealogia. Polska elita polityczna w wiekach średnich na tle porównawczym, red. J. Wroniszewski, Toruń 1993, s. 35-60.

Kurtyka J., Tęczyńscy. Studium z dziejów polskiej elity możnowładczej w średniowieczu, Kraków 1997.

Łętowski L., Katalog biskupów, prałatów i kanoników krakowskich, t. 1, Kraków 1852, s. 182-216.

Maciejewski J., Episkopat polski doby dzielnicowej 1180-1320, Kraków-Bydgoszcz 2008.

Maciejowski M., Orientacje polityczne biskupów metropolii gnieźnieńskiej 1283-1320, Kraków 2007.

Marecki E., Ugody księcia Leszka Czarnego z biskupem Pawlem z Przemankowa, „Studia Historyczne" 1986, z. 2, s. 263-268. 
Nowakowski T., Małopolska elita władzy wobec rywalizacji o tron krakowski w latach 1288-1306, Bydgoszcz 1992.

Ożóg K., Formacja intelektualna biskupów krakowskich w średniowieczu, [w:] Cracovia - Polonia - Europa. Studia z dziejów średniowiecza ofiarowane Jerzemu Wyrozumskiemu w sześćdziesiąta piąta rocznicę urodzin i czterdziestolecie pracy naukowej, Kraków 1995, s. 159-177.

Piekosiński F., Rycerstwo polskie wieków średnich, t. 3, Kraków 1901.

Powierski J., Rola Jaćwieży w walce ludów battyjskich z agresją krzyżacka, „Rocznik Białostocki” 1981-1982, nr 14, s. 87-116.

Przeździecki A., Pawet z Przemankowa. Rys historyczny z drugiej połowy XIII wieku w Polsce, nieznanych po większej części lub mało znanych źródet skreślony, „Biblioteka Warszawska” 1851 , t. 2, s. 201-258.

Rybarski A., Udziat Toporczyków w uwięzieniu biskupa krakowskiego, „Kwartalnik Historyczny” 1912 , t. 26 , s. $1-12$.

Semkowicz A., Krytyczny rozbiór Dziejów polskich Jana Dlugosza (do roku 1384), Kraków 1887.

Semkowicz A., Rec. B. Ulanowski, Przyczynek do dziejów Pawła z Przemankowa, Kraków 1883, „Przegląd Powszechny” 1884, t. 2, s. 125-127.

Semkowicz A., Rec. B. Ulanowski, Przyczynek do dziejów Pawła z Przemankowa, Kraków 1883, „Przegląd Powszechny” 1885, t. 6, s. 247-252.

Semkowicz A., Walka o monarchia 1288-1294 (ustęp z dziejów piastowskich), „Kwartalnik Historyczny" 1891, R. 5, s. 727-778.

Sobaniec S., Zabiegi Henryka IV Wrocławskiego o Kraków i jego usiłowania odnowienia Królestwa, [w:] Księga pamiątkowa ku czci Oskara Haleckiego, Warszawa 1935, s. 229-248.

Sochacka A., Problemy genealogii Półkozów Czyżowskich, [w:] Ludzie i herby w dawnej Polsce, red. P. Dymmel, Lublin 1995.

Swieżawski A., Przemyst - król Polski, Warszawa 2006.

Teterycz-Puzio A., Matopolska elita władzy wobec zamieszek politycznych w Matopolsce w XIII wieku, „Społeczeństwo Polski Średniowiecznej” 2001, t. 9, s. 65-87.

Tęgowski J., Zabiegi księcia kujawskiego Władystawa Łokietka o tron krakowski w latach 1288 1293, „Zapiski Kujawsko-Dobrzyńskie. Historia” 1988, t. 6, s. 43-67.

Trawka R., Instrumenty oddziaływania społeczeństwa na władcę w średniowieczu w Polsce Piastów do końca XIII w., „Rocznik Muzeum w Gliwicach” 1991/1992, t. 7/8, s. 29-45.

Ulanowski B., Przyczynek do dziejów Pawła z Przemankowa, „Rozprawy i Sprawozdania z Posiedzeń Wydziału Historyczno-Filozoficznego Akademii Umiejętności” 1884, t. 17, s. 92-117.

Urzędnicy małopolscy XII-XV wieku. Spisy, oprac. J. Kurtyka, T. Nowakowski, F. Sikora, A. Sochacka, P.K. Wojciechowski, B. Wyrozumska, red. A. Gąsiorowski, Wrocław 1990.

Włodarski B., Polityczna rola biskupów krakowskich w XIII wieku, „Nasza Przeszłość” 1967, t. 27 , s. 29-62.

Wojciechowski P.K., Ugrupowania polityczne w ziemiach krakowskiej i sandomierskiej $w$ latach 1280-1286, „Przegląd Historyczny” 1979, z 1, s. 57-72.

Wyrozumski J., Pawet z Przemankowa, [w:] Polski Stownik Biograficzny, t. 28: 1984-1985, s. 391394.

Żmudzki P., Studium podzielonego królestwa. Książę Leszek Czarny, Warszawa 2000. 


\section{SUMMARY}

The life and political activity of the Bishop of Cracow, Paweł of Przemanków is connected with various accusations and aspersions saved in medieval narrative sources. Some of them have a political character, including accusations of the bishop's participation in rebellions against Cracow-Sandomierz dukes and connections with Lithuanian invasions. The remaining accusations are connected with his shortcomings and attitude, describing his nature as wicked or accusing him of leading immoral life, simony or murder.

Keywords: Bishops of Cracow; Cracow-Sandomierz duchy; dark legend 